\title{
Global Learning for Sustainable Development: A Historical Review
}

\author{
Birgitta Nordén $1, *,+(\mathbb{D}$ and Helen Avery $2,3,4,+\mathbb{D}$ \\ 1 Faculty of Education and Society, Malmö University, 20506 Malmö, Sweden \\ 2 Centre for Advanced Middle Eastern Studies, Lund University, 22100 Lund, Sweden; helen.avery@cme.lu.se \\ 3 Centre for Environmental and Climate Science, Lund University, 22100 Lund, Sweden \\ 4 Department of Languages, Linnaeus University, 35195 Växjö, Sweden \\ * Correspondence: birgitta.norden@mau.se \\ + Co-first author, these authors contributed equally to this work.
}

check for

updates

Citation: Nordén, B.; Avery, H. Global Learning for Sustainable Development: A Historical Review. Sustainability 2021, 13, 3451. https://doi.org/10.3390/su13063451

Academic Editor: Gisela Cebrián

Received: 22 September 2020

Accepted: 16 March 2021

Published: 20 March 2021

Publisher's Note: MDPI stays neutral with regard to jurisdictional claims in published maps and institutional affiliations.

Copyright: (c) 2021 by the authors. Licensee MDPI, Basel, Switzerland. This article is an open access article distributed under the terms and conditions of the Creative Commons Attribution (CC BY) license (https:/ / creativecommons.org/licenses/by/ $4.0 /)$.

\begin{abstract}
Despite continued efforts by educators, UN declarations and numerous international agreements, progress is still limited in handling major global challenges such as ecosystem collapse, accelerating climate change, poverty, and inequity. The capacity to collaborate globally on addressing these issues remains weak. This historical review of research on global learning for sustainable development (GLSD) aims to clarify the diverse directions that research on GLSD has taken, to present the historical development of the research area, and highlight emerging research issues. The review summarizes key findings of 53 peer-reviewed publications, published in English in the period 1994-2020 identified with the search terms "global learning" and "sustainable development", sustainability or GLSD, respectively. The review documented a gradually growing knowledge base, mostly authored by scholars located in the global North. Conclusions point to what we might achieve if we could learn from one another in new ways, moving beyond Northern-centric paradigms. It is also time to re-evaluate core assumptions that underlie education for sustainable development more generally, such as a narrow focus on formal learning institutions. The review provides a benchmark for future reviews of research on GLSD, reveals the emerging transformative structure of this transdisciplinary field, and offers reference points for further research.
\end{abstract}

Keywords: global learning; global learning for sustainable development; South/North perspectives; sustainability; sustainable development; education for sustainable development

\section{Historical Background of the Field-Agenda 21 and Learning for Sustainable Development}

Both education for sustainable development (ESD) and global learning for sustainable development (GLSD) were catalyzed by the Rio Earth Summit of 1992 [1] and Agenda 21 [2]. At that time, it was clear that the planet was facing unprecedented challenges, which could only be addressed collectively. The call to action of the 1987 Brundtland report [3] recognized that environmental issues were closely connected to social and economic issues. International cooperation and solidarity were recognized as essential ([1] principle 5, 6, 7; [2] $1.1,2.1 ;[3])$, since merely pushing towards economic growth would lead to environmental disaster, without resolving the pressing challenges of the developing countries ([2] 3.2; [3]). The declarations at Rio acknowledged the gravity of the situation, but the mood was also optimistic. Although the challenges were serious, the steps to change course from the path of disaster to a brighter future seemed simple and feasible. It was in the interest of everyone to avoid rendering the planet inhabitable. The states forming the UN were prepared to join in shared efforts.

The notion of "sustainable development" was from the outset linked to the UN agendas for "development", which classified countries according to a range of development criteria and indicators. Since countries that according to this classification were seen as "developing" had less scope of action, the "developed" countries would have to make particular investments in sustainable development ([1] principle 6, 7). An additional 
argument was that "developed" countries drew on resources across the world at the same time that they had a much greater environmental footprint per capita. Coming from the UN, this was a top-down agenda, but it was supported by numerous NGOs, and the necessary coordination of efforts required the international structures that the UN could offer. The practices of certain industries were unsustainable, but the underlying assumption at Rio was that these industries could be "greened" and converted to more sustainable modes of production. There was also a risk that citizens might not be willing to change unsustainable habits, but it was assumed that this could be averted through information, education, and increased awareness.

The Brundtland report of 1987 [3] pointed to the causes of environmental crisis and the need to change, but above all to a concern for the future and future generations. The role of teachers and educational institutions was explicitly mentioned in Brundtland's introduction to the report, but also "citizen" groups, non-governmental organizations, and the scientific community. International development strategies have in the decades since Rio primarily been concerned with formal education, particularly primary compulsory schooling, since this is guaranteed through the "right to education" stipulated in various UN documents. The understanding of global learning for sustainable development has therefore to some extent been delimited and limited by its origins as part of this broader international UNdriven development discourse [4,5]. The focus on formal education for implementing sustainable development has entailed a framing of learning as preparation for the future lives of individual students, rather than "social learning" [6,7], life-long informal/nonformal learning, or learning as developing capacity for collective action (i.e., learning to self-organize, mobilize resources, and further strengthen organizational capacity).

Rio [1] in many ways marked a decisive turning point in shaping a perception of common efforts for a shared goal-bringing together national governments, NGOs, international organizations, and educators worldwide. However, the ideas and practices mobilized by Rio drew on movements and debates from the preceding decades. Already since the 1950s, activists and researchers had been pointing to the dangers of environmental destruction. Powerful social movements were engaged in combatting social and global injustices, as well as the threats of intolerance, racism, militarization, and warfare. Numerous bodies, organizations, and international agencies were working on issues such as eliminating poverty, ensuring safe water supplies, developing renewable energy sources, reducing pollution, fighting acid rains, conserving species, or reversing desertification. These experiences ultimately fed into the fields of both ESD and GLSD [8].

To achieve consensus and start moving, the vision at Rio was to focus on the intersection of the "economic", the "environmental", and the "social", that is, actions that would produce a win-win situation with immediate benefits for all. The supposition was that focusing on changes that could be made within the intersection of the three domains would incrementally lead to increased sustainability, and this process could continue until sustainable development had been achieved. The "three pillar" or "three sphere" conception of sustainable development that came to dominate later efforts originated in debates during the 1970s on economics, development, and global relationships [9]. In the context of the Brundtland report [3] and Rio [1], the aim was to coordinate and integrate international social and economic development work with environmental constraints. Rio did not challenge the notion that economic growth was necessary to reduce the global poverty gap, and Agenda 21 [2] $2.9 \mathrm{~d}$. thus includes the aim: "To promote and support policies, domestic and international, that make economic growth and environmental protection mutually supportive". Agenda 21 thereby placed sustainable development within a paradigm of global trade liberalization as well as of "technocentrism" [10].

\section{Global Learning for Sustainable Development}

The field of global learning for sustainable development (GLSD) lies at the intersection of the fields of global learning (GL) and the field of education for sustainable development (ESD). Many publications on GLSD therefore overlap with ESD or with GL. However, 
much of the research in ESD does not focus on global learning, just as much of the research on GL does not have a specific focus on sustainability. Additionally, the term "learning" in GLSD takes on wider meanings than those that are usual in formal education contexts. For the purposes of this study, we follow Schugurensky's [11] definition of formal education as education organized to lead to diplomas or certificates that allow graduates to proceed to the next level or gain access to jobs that require certification. The distinction is not sharp, however, since learning in formal education contexts can involve aspects that are not related to qualifications, while learning ensuing from involvement in civil society organizations may be recognized by employers for certain jobs.

Like ESD, GLSD takes its point of departure in the call for action of the Brundtland report [3] and initially also in the framing of sustainability and development outlined in Rio [1,2]. Compared to ESD, which focuses on teaching and learning in formal educational institutions, GLSD comprises the wider aspects of informal and social learning that were also outlined in the Brundtland report, as well as the numerous ways in which formal education institutions collaborate with each other for sustainability, and with other organizations and groups in society. While certain authors make a distinction between learning and action for sustainable development, this review therefore includes the wider questions of social learning, learning through collaboration across different countries and contexts, learning through action, and learning to take action.

In the literature, besides the connections to ESD, the field of GLSD also partly overlaps with other areas such as "global citizenship education", "development education", or "global education" (GE). These areas cover a wide range of topics and approaches $[8,12,13]$ linked by a broad concern with issues of global social justice and/or understanding global challenges. Although the expressions are sometimes used interchangeably, the term "global learning" generally places emphasis on the learners and learning processes [14,15], as well as including organizational learning, capacity-building, and social learning. Barker [16] describes global learning as transformational, emancipatory, and rooted in learners' own experiences. By contrast, the term "education" to a greater extent stresses the (mostly formal) institutional structures and policies that intentionally shape contexts for learning.

\section{Aim}

This historical literature review aims to show the diverse directions that research on GLSD has taken since its inception, and to present the historical development of the research area since Rio. In particular, we wish to identify topics of debate where diverging opinions are voiced, summarize the main conclusions from the studies, and identify challenges that need to be addressed. As a subfield of the wider notions of both global learning (GL) and education for sustainable development (ESD), the discussion will include works from both these fields with relevance to GLSD.

\section{Reviews of ESD Literature}

A few recent comprehensive reviews of ESD research examine publication patterns and point to some major topics. Aikens et al.'s [4] review researches sustainable education policy research for the period 1974-2013. Grosseck et al. [17] covers all levels of education, while Bascopé et al. [18] look at early childhood education, Hallinger and Nguyen [19] examine K-12 schooling, and Hallinger and Chatpinyakoop [20] cover higher education for sustainable development (HESD).

In their review on sustainable education policy research for the period 1974-2013, Aikens et al. [4] found that the US, the UK, Australia, China/Hong Kong, and Australia made up over half the publications. The term environmental education was used in the 1970s, 80s, and 90s. The term education for sustainable development first appeared in UN documents in 1980, but only gained currency through the Brundtland report of 1987 [3] and rose sharply after 2005 in connection with the DESD. Since then, the use of the term sustainability has increased. Although climate change is listed in the Brundtland 
report among the major challenges facing the planet, the research on policy reviewed by Aikens et al. [4] observe that it did not start to appear in publications until after 2006.

The majority of publications covered in Aikens et al.'s review [4] describe policy as driven by the international agendas, although some also mention pressure from NGOs. Several publications are critical to an internationally driven agenda dominated by the global North and international funding agencies, which has not sufficiently involved local actors. ESD goals were critiqued for supporting business as usual with a neoliberal agenda, as well as for focusing on economic growth rather than devoting attention to the causes of poverty. The notion of SD was also critiqued for framing environmental protection as a way to preserve resources, reflecting an anthropocentric perspective. In curricula, sustainability was overwhelmingly linked to natural science subjects.

The bibliometric review of 1813 Web of Science indexed ESD publications for the period 1992-2018 by Grosseck et al. [17] includes not only journal articles and books, but also conference papers. Although they had not deliberately excluded other languages in their search, all 1813 publications reviewed were in English, and co-authoring patterns showed little global international collaboration. The main subject categorizations of the publications found by Grosseck et al. [17] were educational research (60\%), green sustainable science technology (31\%), environmental studies $(23 \%)$, and environmental sciences $(17 \%)$. Only 37 publications were found until 2004, while 1073 of the reviewed publications were from the period 2014-2018. Papers after 2015 largely concern achieving SD through education, but with a focus on SDG 4. The ten most cited publications were Wiek et al., 2011 [21], and six other publications on HESD, Jickling and Wals, 2008 [6], UNESCO, 2005 [22] and the Brundtland report [3].

Writing from a Chilean perspective, Bascopé et al. [18] conducted a systematic review of a total of 56 ESD publications in early childhood education, including publications in both English and Spanish. They highlight the need for an interdisciplinary approach to educating children to become change-agents grounded in places. Weaknesses identified in early childhood education and sustainability approaches include adult-centric views on children that consider them incapable of dealing with serious issues, the need to develop experience, overcoming both romanticized and positivistic views on human relationships with the environment, and integrating individual and collective values. In contrast to much of the literature from the global North, their review places ESD not only as comprising environmental education, citizenship education, etc., but also as including communitybased education as a cornerstone (present in half of the articles they reviewed). The authors advocate action-based learning that integrates knowledge and experience, considering children as active stakeholders in sustainability issues and supporting agency.

A bibliometric review was made by Hallinger and Nguyen [19] of 1842 Scopus-listed ESD publications in English for the period 1990-2019 concerning K-12 schooling. They observe that ESD is now also understood as a sub-field of sustainability science. Publications increased slowly in the period preceding 2005, but the UN decade of education for sustainable development (DESD) 2005-2014 [22] sparked a steep rise in ESD publications. The majority of ESD publications come from the global North, in particular the UK, the US, Australia, Sweden, Germany, Canada, and the Netherlands. Among developing countries, the literature was dominated by China, South Africa, Brazil, and Turkey.

The bibliometric review of Hallinger and Chatpinyakoop [20] covers Scopus-listed research on higher education for sustainable development (HESD) in the period 19982018. Their search found 81 publications in the period 1998-2004, 380 for the period 2005-2011, and 998 in the period 2012-2018, indicating an accelerating interest in the field. Fifty five percent of the publications were produced by researchers from the US, the UK, Canada, and Australia. Only 16\% of the publications came from developing countries, and these were almost exclusively from after 2010. The two most cited HESD publications concerned key competencies $[21,23]$. The other main themes were definitions of HESD, implementation challenges, managing for sustainability in HE (e.g., sustainability assessment and reporting), curriculum, and teaching and learning approaches. 


\section{Method}

\subsection{Choice of Search Terms}

The search terms used in our review of GLSD are "global learning", combined with "sustainability" and "sustainable development", respectively. The area of GLSD can be approached from a range of different angles, including research on development policy or sustainability studies. The present study is above all concerned with the dimension of learning. It therefore connects closely to, and partly overlaps with, the field of education for sustainable development. However, in our search, the term ESD has not been used, since our aim has been to include ESD research that deals with global learning, but to exclude ESD research with other types of focus.

Considering the numerous international documents that have marked the decades since the Brundtland report and the 1992 Earth Summit, we have also chosen not to use the specific names of development targets as search terms (e.g., Agenda 21, Millenium Development Goals, Sustainable Development Goals). Instead, we have focused on the two terms "sustainable development" and "sustainability", which were employed already in Agenda 21 [2] and which have continued to be used throughout the period. Our overview does not aim to make a comprehensive discussion of the various definitions but will touch upon aspects of diverse ways of understanding sustainable development and sustainability that have implications for the goals and forms of GLSD.

\subsection{Search and Screening}

An initial search was made in Scopus on 27 April 2020, for publications in English with the search terms "global learning" AND "sustainability", "global learning" AND "sustainable development", excluding conference presentations. The search resulted in only 21 publications for the first combination, and 12 publications for the second. An updated search on 19 October 2020, in Scopus using the same search terms and criteria yielded no further publications. The combined Scopus searches resulted in a total of 26 items.

A further search was made using the same search terms on 26 November 2020, in Web of Science Core Collection-Indexes: SCCI, APA PsycINFO, and ERIC, yielding a total of 31 additional items. PubMED was searched with the same search terms but yielded no publications. The majority of new publications identified were found in ERIC $(n=27)$ and published in International Journal of Development Education and Global Learning. The search and screening process is summarized in Figure 1, and results are listed in Table 1.

The search terms found in abstracts and keywords can have different meanings, and we wished to include the entire range of variation in perspectives. In the initial screening, only six publications that appeared in the searches were therefore excluded. These were: Schrüfer, Schwarze, and Obermaier, 2018 (full text in German); Ito and Nakayama, 2014 (concerns ESD but not global learning); Kertyzia and Standish 2019 (peace education in Mexico); O'Brien and Murray, 2015 (entrepreneurship, no global learning, sustainability only understood as business viability); Lambert and Jones, 2013 (global learning and sustainability treated in separate chapters); and Boyden et al. 2018 (concerns preventing violence against children). An additional eight publications authored or co-authored by Nordén were excluded to avoid self-referencing. The combined searches yielded a total of 53 publications (Figure 1). The majority of publications found in the various searches were read in full text, both for the initial screening and for the analysis of the publications that were retained. However, two books, Gaudelli, 2016 [24], and Peterson and Warwick, 2014 [25], were only partly read.

To deepen the discussion and facilitate future research on GLSD, besides the publications found in the searches described above, our review includes additional literature. This comprises a few further publications by authors that appeared in the searches, ESD bibliometric reviews, foundational UN documents pertaining to global learning and sustainable development, and key references central to the arguments of the reviewed publications, as well as some additional literature on the main topics that emerged in this study. 

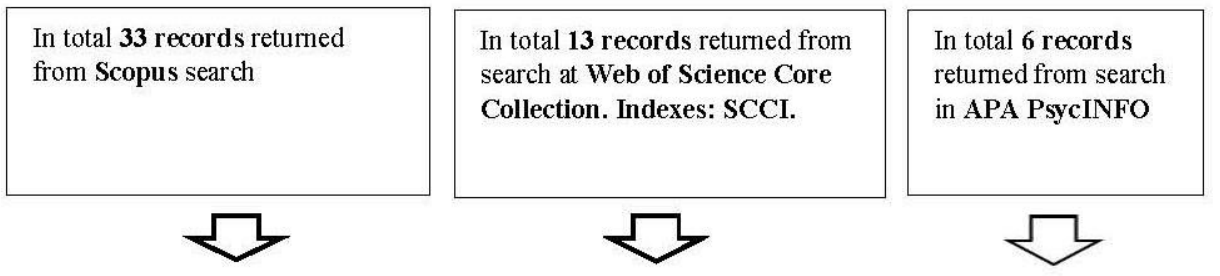

In total $\mathbf{4 2}$ records

returned from ERIC

database search
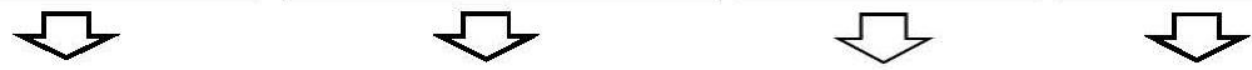

In total 94 records returned after searches in the databases, and

exclusion of duplicate publications resulted in 27 records removed

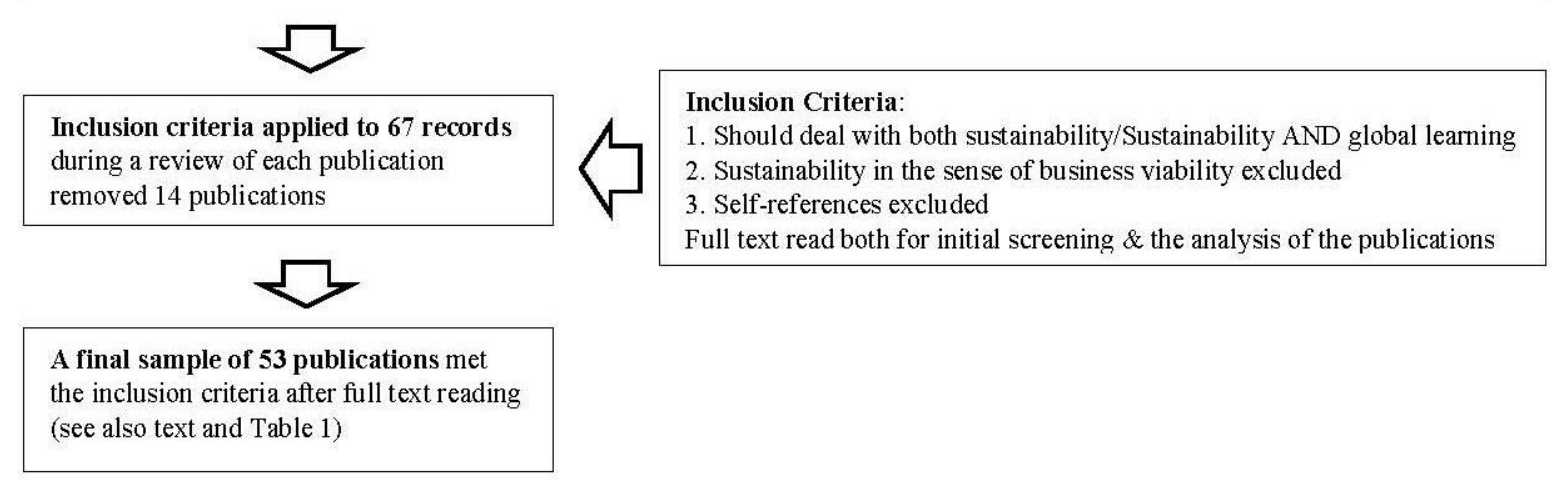

Figure 1. Search and screening process of flowchart with decision tree.

Table 1. Search in the databases Scopus, SSCI, PsycInfo, and ERIC with search terms: "global learning" and "sustainability" / "sustainable development" (19 October-26 November 2020).

\begin{tabular}{|c|c|c|c|}
\hline Year of Publication & Article Title & Authors & $\begin{array}{l}\text { Searched Keywords A } \\
\text { and/or B/Databases }\end{array}$ \\
\hline 2020 & $\begin{array}{l}\text { The erasures of racism in education } \\
\text { and international development: } \\
\text { re-reading the 'global learning crisis'. }\end{array}$ & $\begin{array}{l}\text { Sriprakash, A., Tikly, L., } \\
\text { Walker, S. }\end{array}$ & A/Scopus + B/SSCI + ERIC \\
\hline 2020 & $\begin{array}{l}\text { A historical perspective on the } \\
\text { OECD's 'humanitarian turn': PISA } \\
\text { for Development and the Learning } \\
\text { Framework } 2030 \text {. }\end{array}$ & Xiaomin, L., Auld, E. & A/Scopus + B/SSCI \\
\hline 2020 & $\begin{array}{l}\text { Global Learning from the Periphery: } \\
\text { An Ethnographic Study of a Chinese } \\
\text { Urban Migrant School. }\end{array}$ & Dong, J. & $\mathrm{AB} / \mathrm{SSCI}$ \\
\hline 2020 & Different schools, different cultures. & $\begin{array}{l}\text { Heto, P.P.-K., Odari, M.H., } \\
\text { Sunu, W.K. }\end{array}$ & A/Scopus \\
\hline 2020 & $\begin{array}{l}\text { How Children Living in Poor } \\
\text { Informal Settlements in the Greater } \\
\text { Accra Region, Ghana, Perceive Global } \\
\text { Citizenship. }\end{array}$ & Leithead, J., Humble, S. & A/ERIC \\
\hline 2019 & $\begin{array}{l}\text { The United Nations Sustainable } \\
\text { Development Goals as a Global } \\
\text { Content Framework? }\end{array}$ & Maguth, B.M.; Yang, H. & B/ERIC \\
\hline
\end{tabular}


Table 1. Cont.

\begin{tabular}{|c|c|c|c|}
\hline Year of Publication & Article Title & Authors & $\begin{array}{l}\text { Searched Keywords A } \\
\text { and/or B/Databases }\end{array}$ \\
\hline 2019 & $\begin{array}{l}\text { Universal Values as a Barrier to the } \\
\text { Effectiveness of Global Citizenship } \\
\text { Education: A Multimodal Critical } \\
\text { Discourse Analysis. }\end{array}$ & Hatley, J. & $\mathrm{AB} / \mathrm{ERIC}$ \\
\hline 2019 & $\begin{array}{l}\text { Socio-Scientific Inquiry-Based } \\
\text { Learning: An Approach for Engaging } \\
\text { with the } 2030 \text { Sustainable } \\
\text { Development Goals through School } \\
\text { Science. }\end{array}$ & Amos, R., Levinson, R. & B/ERIC \\
\hline 2019 & $\begin{array}{l}\text { International Development } \\
\text { Volunteering: An Instrument for } \\
\text { Promoting Education in Line with the } \\
\text { Sustainable Development Goals? }\end{array}$ & $\begin{array}{l}\text { Scheinert, L., Guffler, K., } \\
\text { Polak, J.T. }\end{array}$ & B/ERIC \\
\hline 2019 & $\begin{array}{l}\text { Toward One World or Many? A } \\
\text { Comparative Analysis of OECD and } \\
\text { UNESCO Global Education Policy } \\
\text { Documents. }\end{array}$ & Vaccari, V. Gardinier, M.P. & B/ERIC \\
\hline 2019 & $\begin{array}{l}\text { North-South-South Collaboration as a } \\
\text { Context for Collaborative Learning } \\
\text { and Thinking with Alternative } \\
\text { Knowledges. }\end{array}$ & $\begin{array}{l}\text { Riitaoja, A.-L., Posi-Ahokas, } \\
\text { H., Janhonen-Abruquah, H. }\end{array}$ & B/ERIC \\
\hline 2019 & $\begin{array}{l}\text { The case for inclusion of international } \\
\text { planning studios in contemporary } \\
\text { urban planning pedagogy. }\end{array}$ & Jones, $\mathrm{P}$. & A/Scopus + B/SSCI \\
\hline 2019 & $\begin{array}{l}\text { Integrating sustainability into higher } \\
\text { education curricula through the } \\
\text { project method, a global learning } \\
\text { strategy. }\end{array}$ & $\begin{array}{l}\text { Fuertes-Camacho, M.T., } \\
\text { Graell-Martín, M., } \\
\text { Fuentes-Loss, M., } \\
\text { Balaguer-Fàbregas, M.C. }\end{array}$ & $\mathrm{AB} / \mathrm{Scopus}+\mathrm{AB} / \mathrm{SSCI}$ \\
\hline 2019 & $\begin{array}{l}\text { Ready or not here I come: A } \\
\text { qualitative investigation of students' } \\
\text { readiness perceptions for study } \\
\text { abroad/away. }\end{array}$ & $\begin{array}{l}\text { Bikos, L.H., Manning, S.B., } \\
\text { Frieders, Z.J. }\end{array}$ & B/PsycInfo \\
\hline 2018 & $\begin{array}{l}\text { International staff exchange: } \\
\text { Evaluation of a collaborative learning } \\
\text { partnership. }\end{array}$ & $\begin{array}{l}\text { Naleppa, M.J., Waldbillig, } \\
\text { A.A. }\end{array}$ & B/Scopus + A/SSCI \\
\hline 2018 & $\begin{array}{l}\text { Intercultural education as a } \\
\text { prerequisite for sustainability. }\end{array}$ & $\begin{array}{l}\text { Schrüfer, G., Schwarze, S., } \\
\text { Obermaier, G. }\end{array}$ & AB/Scopus \\
\hline 2018 & $\begin{array}{l}\text { A review of the literature to inform } \\
\text { the development of a new model of } \\
\text { global placement: The Global } \\
\text { Learning Partnership }\end{array}$ & Lees, J., Webb, G. & A/Scopus \\
\hline 2018 & $\begin{array}{l}\text { Education for sustainable } \\
\text { development: Vision, policy, } \\
\text { practices-an open or closed } \\
\text { 'doorway' for teachers and schools? }\end{array}$ & Chatzifotiou, A. & AB/Scopus \\
\hline 2018 & $\begin{array}{l}\text { Global Learning: A Catalyst for } \\
\text { Curriculum Change. }\end{array}$ & Scoffham, S. & A/ERIC \\
\hline
\end{tabular}


Table 1. Cont.

\begin{tabular}{|c|c|c|c|}
\hline Year of Publication & Article Title & Authors & $\begin{array}{l}\text { Searched Keywords A } \\
\text { and/or B/Databases }\end{array}$ \\
\hline 2018 & $\begin{array}{l}\text { Transformative Cosmopolitan } \\
\text { Education and Gandhi's Relevance } \\
\text { Today. }\end{array}$ & Lang-Wojtasik, G. & A/ERIC \\
\hline 2018 & $\begin{array}{l}\text { Critical Realist Approaches to Global } \\
\text { Learning: A Focus on Education for } \\
\text { Sustainability. }\end{array}$ & Khazem, D. & A/ERIC \\
\hline 2018 & $\begin{array}{l}\text { Decolonizing Development } \\
\text { Education Policy: The Case of } \\
\text { Germany. }\end{array}$ & Bendix, B. & B/ERIC \\
\hline 2017 & $\begin{array}{l}\text { Sustainable Knowledge } \\
\text { Transformation in and through } \\
\text { Higher Education: A Case for } \\
\text { Transdisciplinary Leadership. }\end{array}$ & Khoo, S.-M. & $\mathrm{AB} / \mathrm{ERIC}$ \\
\hline 2017 & $\begin{array}{l}\text { Becoming Critical: A Challenge for } \\
\text { the Global Learning Programme? }\end{array}$ & Huckle, J. & B/ERIC \\
\hline 2016 & $\begin{array}{l}\text { Sustainable distance learning for a } \\
\text { sustainable world. }\end{array}$ & Bell, S. & AB/PsycInfo \\
\hline 2016 & $\begin{array}{l}\text { Global citizenship education: } \\
\text { Everyday transcendence. }\end{array}$ & Gaudelli, W. & B/Scopus \\
\hline 2016 & $\begin{array}{l}\text { Understanding Learning in World } \\
\text { Society: Qualitative Reconstructive } \\
\text { Research in Global Learning and } \\
\text { Learning for Sustainability. }\end{array}$ & $\begin{array}{l}\text { Scheunpflug, A., Krogull, S., } \\
\text { Franz, J. }\end{array}$ & A/ERIC \\
\hline 2016 & $\begin{array}{l}\text { Global Learning and Development as } \\
\text { an Engagement Strategy for Christian } \\
\text { Higher Education: A Macro Study. }\end{array}$ & Decker, A., Hawkins, G. & B/ERIC \\
\hline 2016 & $\begin{array}{l}\text { Protecting the Future: the Role of } \\
\text { School Education in Sustainable } \\
\text { Development-An Indian Case Study. }\end{array}$ & Bangay, C. & B/ERIC \\
\hline 2016 & $\begin{array}{l}\text { Analysing Key Debates in Education } \\
\text { and Sustainable Development in } \\
\text { Relation to ESD Practice in Viet Nam. }\end{array}$ & Balls, E. & B/ERIC \\
\hline 2015 & $\begin{array}{l}\text { Education for Sustainable } \\
\text { Development and Global Citizenship: } \\
\text { Leadership, Collaboration, and } \\
\text { Networking in Primary Schools. }\end{array}$ & Bennell, S.J. & B/ERIC \\
\hline 2015 & $\begin{array}{l}\text { CLICK: Arts Education and Critical } \\
\text { Social Dialogue within Global Youth } \\
\text { Work Practice. }\end{array}$ & Aubrey, M. & B/ERIC \\
\hline 2015 & $\begin{array}{l}\text { Civic Education for Sustainable } \\
\text { Development and Its Consequences } \\
\text { for German Civic Education Didactics } \\
\text { and Curricula of Higher Education. }\end{array}$ & Brunold, A.O. & $\mathrm{AB} / \mathrm{ERIC}$ \\
\hline 2015 & $\begin{array}{l}\text { The Phenomenon of } \\
\text { "Being-In-Management" in Executive } \\
\text { Education Programmes: An } \\
\text { Integrative View. }\end{array}$ & Sewchurran, K., McDonogh, J. & A/ERIC \\
\hline 2015 & $\begin{array}{l}\text { The creation of interactive activity } \\
\text { pods at a Recycling Education Centre. }\end{array}$ & Pickford, T., Ellis, L. & A/Scopus \\
\hline
\end{tabular}


Table 1. Cont.

\begin{tabular}{|c|c|c|c|}
\hline Year of Publication & Article Title & Authors & $\begin{array}{l}\text { Searched Keywords A } \\
\text { and/or B/Databases }\end{array}$ \\
\hline 2014 & $\begin{array}{l}\text { Global Learning for Global Colleges: } \\
\text { Creating opportunities for greater } \\
\text { access to international learning for } \\
16-25 \text { year olds. }\end{array}$ & $\begin{array}{l}\text { Bentall, C., Bourn, D., } \\
\text { McGough, H., Hodgson, A., } \\
\text { Spours, K. }\end{array}$ & A/Scopus + ERIC \\
\hline 2014 & $\begin{array}{l}\text { Global Learning and Education: Key } \\
\text { Concepts and Effective Practice. }\end{array}$ & Peterson, A., Warwick, P. & AB/Scopus \\
\hline 2014 & $\begin{array}{l}\text { Island development: Local } \\
\text { governance under globalization. }\end{array}$ & Tsai, H.-M., Hong, S.-K. & B/Scopus \\
\hline 2014 & $\begin{array}{l}\text { Success and failure of grassroots } \\
\text { innovations for addressing climate } \\
\text { change: The case of the transition } \\
\text { movement. }\end{array}$ & Feola, G., Nunes, R. & B/Scopus + A/SSCI \\
\hline 2014 & $\begin{array}{l}\text { Making a MEAL out of a Global } \\
\text { Professional Learning Community: A } \\
\text { Transformative Approach to Global } \\
\text { Education. }\end{array}$ & MacCallum, C.; Salam, I. & B/ERIC \\
\hline 2014 & $\begin{array}{l}\text { Global Citizenship as a Floating } \\
\text { Signifier: Lessons from UK } \\
\text { Universities. }\end{array}$ & Moraes, S.E. & A/ERIC \\
\hline 2014 & $\begin{array}{l}\text { World-Mindedness of Students and } \\
\text { Their Geography Education at } \\
\text { International (IB-DP) and Regular } \\
\text { Schools in the Netherlands. }\end{array}$ & $\begin{array}{l}\text { Béneker, T., van Dis, H., van } \\
\text { Middelkoop, D. }\end{array}$ & A/ERIC \\
\hline 2013 & $\begin{array}{l}\text { Mathematics Education Meets } \\
\text { Development Education: The } \\
\text { Competency 'Mathematical } \\
\text { Modelling' Combined with Global } \\
\text { Skills and Competencies in a } \\
\text { Secondary School Project in Germany. }\end{array}$ & Schell-Straub, S. & B/ERIC \\
\hline 2013 & $\begin{array}{l}\text { Learning \& transformative networks } \\
\text { to address wicked problems: A } \\
\text { golden invitation. }\end{array}$ & $\begin{array}{l}\text { Waddell, S., McLachlan, M., } \\
\text { Dentoni, D. }\end{array}$ & B/Scopus + A/SSCI \\
\hline 2013 & $\begin{array}{l}\text { A review of clean energy innovation } \\
\text { and technology transfer in China. }\end{array}$ & Liu, H., Liang, D. & A/Scopus \\
\hline 2012 & $\begin{array}{l}\text { Critical distance: doing development } \\
\text { education through international } \\
\text { volunteering. }\end{array}$ & Diprose, K. & $\mathrm{B} / \mathrm{SSCI}$ \\
\hline 2010 & $\begin{array}{l}\text { The Earth Charter Goes Interactive } \\
\text { and Live with e-GLO: Using New } \\
\text { Media to Train Youth Leaders in } \\
\text { Sustainability on Both Sides of the } \\
\text { Digital Divide. }\end{array}$ & Sheehan, M., Laitinen, J. & $\mathrm{AB} / \mathrm{ERIC}$ \\
\hline 2008 & $\begin{array}{l}\text { Play locally, learn globally: Group } \\
\text { selection and structural basis of } \\
\text { cooperation. }\end{array}$ & Choi, J.-K. & A/Scopus \\
\hline 2007 & $\begin{array}{l}\text { Regional Centres of Expertise: } \\
\text { Innovative Networking for Education } \\
\text { for Sustainable Development. }\end{array}$ & Fadeeva, Z., Mochizuki, Y. & B/ERIC \\
\hline
\end{tabular}


Table 1. Cont.

\begin{tabular}{llll}
\hline Year of Publication & Article Title & Authors & \multicolumn{1}{c}{$\begin{array}{c}\text { Searched Keywords A } \\
\text { and/or B/Databases }\end{array}$} \\
\hline 2006 & $\begin{array}{l}\text { The United Nations decade of } \\
\text { education for sustainable } \\
\text { development, its consequences for } \\
\text { international political education, and } \\
\text { the concept of global learning. }\end{array}$ & Brunold, A.O. & A/Scopus \\
\hline 2006 & $\begin{array}{l}\text { School development through } \\
\text { Education for Sustainable } \\
\text { Development in Austria. }\end{array}$ & Rauch, F., Steiner, R. & A/Scopus + B/PsycInfo + \\
\hline 2005 & $\begin{array}{l}\text { Global learning and education for } \\
\text { sustainable development. }\end{array}$ & Brunold, A.O. \\
\hline & $\begin{array}{l}\text { Information Technology and Global } \\
\text { Learning for Sustainable } \\
\text { Development: Promise and Problems. }\end{array}$ & Hall, B.W. & A/Scopus + ERIC \\
\hline
\end{tabular}

[Note: A = global learning AND sustainability; $\mathrm{B}$ = global learning AND sustainable development; $\mathrm{AB}$ = global learning AND sustainability + global learning AND sustainable development].

\section{Thematic Analysis of Reviewed Publications}

The reviewed literature comprises a very wide range of topics and includes both empirical studies and theoretical work. We do not aim to make a comprehensive content analysis of this body of literature, but rather provide an overview of main findings and the diverse topics that are treated. For the readers' convenience, we have grouped the literature under the following broad themes: general and historical overviews, theoretical contributions, policy research; research on formal primary and secondary education contexts; research in further and higher education contexts; social learning and learning outside formal education contexts; and North-South relationships. Topics and empirical findings are summarized in Table 2.

\subsection{General and Historical Overviews}

A few of the reviewed publications offer a general picture both of research conducted in the field, and the broader institutional and political landscape within which global learning for sustainable development takes place. Authors critically discuss tensions within the field related to different ideological stances, as well as arguing for the role GLSD can play and outlining possible future directions.

Rauch and Steiner [12] give an overview of the historical development of environmental education and global learning in the German speaking countries since the 1950s. They argue for a convergence of these fields and highlight the need for national policies to support educational development for sustainability in the area. Rauch and Steiner stress that global learning is not about conveying factual knowledge, but is a critical approach to concerns, interests, and experiences. Global learning per se cannot serve to create a better world but encourages self-determination in a global context.

Brunold [26] also traces significant moments in the history of global learning for sustainable development, going back to the origins in international policies for environmental education (EE) in the 1970s, connecting these initiatives with the field of global learning, and the ambitions of the UN decade of education for sustainable development (DESD) [22]. Brunold highlights some of the significant challenges within the debates, including what kind of globalization is envisaged, what mechanisms for global governance exist, and to which extent the ambition of developing the economies of the so-called developing nations is compatible with sustainability targets. Finally, he highlights the potentials of lifestyle changes, informed consumers, and informed citizens who will support sustainable policies in their countries. 
Gaudelli [8] previously explored global citizenship linked to five different discoursesneoliberal, nationalist, Marxist, world justice/governance, and cosmopolitan-which have various political and epistemological stances In Gaudelli's recent work [24], he underlines the problems connected to a dominant neoliberal discourse and further examines the tensions between different understandings of globalization and education, leading to diverging implications for global citizenship. The book gives a comprehensive overview of the field, including how issues of global learning relate to sustainability. Gaudelli also discusses the differences in perspectives on global learning coming from elite institutions and perspectives emanating from marginalized populations. Another comprehensive overview of the field of global learning is provided by Peterson and Warwick [25], who conclude that to grasp which challenges the field will face in the coming years, we should engage with the approaches and questions raised in future studies.

Table 2. Thematic overview of findings and topics debated in reviewed publications 1994-2020.

\begin{tabular}{ll}
\hline & Historical context and development of field; \\
General and historical overviews & $\begin{array}{l}\text { ideological divergences; need for and value of GLSD; } \\
\text { suggested future directions }\end{array}$
\end{tabular}
suggested future directions

Knowledge formation, exchange, and transfer; inter-

Theoretical contributions and transdisciplinarity; global-local collaboration and networks; universality or pluralism in values; motivation to engage in collaboration

\begin{tabular}{ll}
\hline Policy research & $\begin{array}{l}\text { International agendas (UN, OECD); national policies } \\
\text { and curricula; choice of learning content and } \\
\text { competencies; need for critical global learning }\end{array}$ \\
\hline \multirow{2}{*}{ Formal primary and secondary education } & $\begin{array}{l}\text { Position of GLSD with respect to curricular content; } \\
\text { student learning outcomes; student motivation; } \\
\text { leadership and whole-school engagement; } \\
\text { collaboration with actors outside schools }\end{array}$ \\
\hline Further and higher education & $\begin{array}{l}\text { Institutional drivers; funding; institutional capacity; } \\
\text { forms of including GLSD content in programs }\end{array}$ \\
\hline Learning outside formal education & $\begin{array}{l}\text { NGO action; global action networks/NGO networks; } \\
\text { practical challenges; diverging priorities; } \\
\text { self-identification as global citizens }\end{array}$ \\
\hline North-South relationships & $\begin{array}{l}\text { Unequal global power relationships; inequalities } \\
\text { within countries; racism; shallow learning from } \\
\text { exchanges; examples of partnerships for GLSD }\end{array}$ \\
\hline & $\begin{array}{l}\text { North-South power imbalances; question of shared } \\
\text { language; issues funding GLSD; weaknesses both in } \\
\text { digitally mediated communication and in physical } \\
\text { exchanges; knowledge does not necessarily lead to } \\
\text { action for sustainability }\end{array}$ \\
\hline
\end{tabular}

\subsection{Theoretical Contributions}

The publications grouped under this theme explore deeper some of the fundamental questions underlying the notion of global learning for sustainable development. These include questions of knowledge formation and transfer, as well as issues of how collaboration is articulated across global and local contexts. With respect to knowledge, attention is given to inter- and transdisciplinarity, as well as to how knowledge can be embedded in local contexts. Work on conditions for collaboration includes issues of values, North-South power relationships, as well as the questions of altruistic mindset and willingness to engage in collective projects.

In an analysis of how globalization impacts education and implications for global learning and sustainability education, Brunold [27] argues that not only learning sustainable attitudes is necessary, but also "unlearning" harmful attitudes. The learning process 
must additionally work to develop public consciousness for change to take place. Brunold further underlines that no substantial connection has been proved between environmental knowledge, attitudes towards the environment and environmental behavior. In a later study, Brunold [28] argues that educational systems play a key role in shaping how action can be taken, since these systems construct human ability to reflect needs. He further contends that mutual exchange and knowledge transfer between the global North and the global South is necessary, both through formal and non-formal education. Brunold raises the question of how international policy such as Agenda 21 [2] can reorganize education to focus on sustainability challenges and argues for the potential of the "One World" concept (see Brunold [29]). The paper also summarizes key competences for ESD.

Choi [30] makes an interesting theoretical contribution to the issue of which structures may favor altruistic cooperative behavior in global-local learning contexts by modeling outcomes of various constellations. Based on this modeling, Choi concludes that the constellation that best supports collaborative and altruistic behavior is local interaction combined with global learning. In Choi's model, since individuals may or may not be "cooperators", the greater variation between groups produced by this constellation produces a greater chance of having some groups consisting mainly of "cooperators". However, the ideal constellation also needs to comprise some local learning to function. Scheunpflug, Krogull, and Franz [31] describe how the documentary method and qualitative reconstructive research can be used to investigate young people's orientation to global education in the context of young people traveling abroad to meet other groups. In this methodological article, implicit orientation and people's own frame of relevance are understood as tacit knowledge.

Khazem [32] argues that from the perspective of critical realism, the issues in global learning for sustainability are a matter of changing structures, rather than just attempting to change a state of affairs. She believes that critical realism is a useful point of departure to deal with problems posed by the interdisciplinary nature of sustainability challenges. In critical realism, knowledge is understood as socially produced, but at the same time the world exists independently of our knowledge about it. This stance helps to deal with different positions and interests concerning sustainability solutions, as well as dealing with the tension between a deterministic understanding of the challenges, on the one hand, and the understanding that challenges are entirely social, on the other. Khoo [33] argues for pragmatic transdisciplinarity in $\mathrm{HE}$, in the sense of collaborative work between different types of actors inside and outside academia to solve complex practical problems. The article further discusses the need for combining such external engagement with internally oriented critical reflection and learning. In particular, Khoo highlights problems in the technoscientific assumption that convergence will arise in working on a problem, which disregards questions of politics and social justice. Finally, Khoo stresses that fragmented projects are not sufficient to create necessary collective thinking, and that supportive structures are required that ensure continuity in reflection as well as wider critical discussions across the disciplines. At a time when ICTs were generally viewed in a positive light within the field of ESD and global learning for sustainable development, Hall [34] makes a significant contribution to the debate on impacts of using ICTs in the context of global learning and sustainable development, with a deep and critical analysis of the stakes and issues involved. These include not only disparities in access and a centering of Northern perspectives, but also issues regarding the kinds of knowledge that can be formed.

In a philosophical essay, Lang-Wojtasik [35] considers global learning through the lens of transformative cosmopolitan education, in order to go beyond neocolonialist framing of global challenges. Lang-Wojtasik discusses how not only spatial relations, but the acceleration of social change globally lead to value conflicts, with the need to consciously reconsider our world views and position in society. He proceeds to describe Gandhi's philosophy, including the question of ensuring equitable livelihoods, grassroots democracy, and ways to achieve unity of action while respecting diversity. Hatley [36] argues that the UNESCO universal values for global citizenship education are counterproductive and recommends instead allowing a concept that can be relevant to local contexts. She further 
contends that the search for commonality has led to UNESCO values that are abstract and disconnected from social realities. Her understanding of global citizenship draws on Barrow [37] (p. 164) and can be summarized as acting for peace and justice, a pluralistic outlook, combined with knowledge and action for global problems.

Scoffham [38] underlines that while multiple understandings of the term "global learning" entail the risk of becoming an amorphous container concept, it should be acknowledged that this is an emerging field, with evolving terminology. His paper points to the problems of assessing global learning in education through measurable outcomes and a predetermined path of progression, since global learning involves values and changes in self-perception. This in turn challenges fundamental assumptions in how learning is conceptionalized and measured in educational settings.

\subsection{Policy Research}

Policy research on GLSD touches on the different agendas of the UN and other international organizations, as well as policies and curricula for national implementation. Different institutional structures and instruments are discussed, but also choice of content and competencies, and the need for critical global learning and citizenship.

GLSD touches on several of the same concerns as global citizenship education. Chung and Park [39] do not explicitly mention GLSD but have analyzed the differences and overlap between global citizenship education and ESD in relation to the wording of the SDGs. Their analysis is undertaken using focused content analysis of reviewed literature, in particular UN documents. Chung and Park note that global citizenship is included in ESD concerns [40], and that ESD can thus serve as an umbrella term for both global citizenship and other ESD activities. However, global citizenship education is mentioned as a distinct objective in the SDGs. Chung and Park stress the need for international collaboration in the field, as well as mentioning both learning in schools and lifelong learning. In line with Torres [41], they draw on Andreotti [42] to conclude that global citizenship education as outlined in UNESCO (2015) [43] resembles what Andreotti calls "critical global citizenship". This encompasses a political dimension and addresses unequal power relations. By contrast, global citizenship in ESD is consistent with what Andreotti terms "soft global citizenship".

Vaccari and Gardinier [44] examine convergences and divergences between the visions of the future expressed by the UN concept of "global citizenship" and the OECD concept of "global competences" in key documents. While both concepts understand individuals as situated in a context of globalization, global relationships, and interdependencies, the UN concept emphasizes a sense of shared humanity and the ability to take action. By comparison, the OECD concept highlights competences required for the workplace, and backgrounds issues of human rights or social justice. Looking at the structural drivers in education globally, Xiaomin and Auld [45] offer a critical analysis of two OECD initiatives first presented in the OECD Vision Statement of 2011. PISA for Development adapts PISA tests to better correspond to low- and middle-income countries, with the ambition of making it the global learning metric. The Learning Framework 2030 incorporates noncognitive competencies into its tests. The authors argue that by framing assessment as a human right and placing it within a humanitarian agenda, the neoliberal discourse that underlies it becomes difficult to oppose. The initiatives discussed in the article have great significance for education globally and are intended to strengthen the influence of the OECD with respect to the interpretation and implementation of the SDGs.

Fadeeva and Mochizuku [46] describe the role of Regional Centers of Expertise on ESD and suggest how these centers can be developed into a "Global Learning Space for Sustainable Development". Regional Centers of Expertise are networks of organizations of formal, nonformal, and informal education, working for ESD at the local and regional levels. From a UN perspective, such networks can facilitate the transfer of "best practices" across organizations in a region. Fadeeva and Mochizuku suggest that networking among the Regional Centers of Expertise would allow the emergence of differentiated thematic 
groups and have benefits in terms of pooling financial and human resources. As these centers involve multiple actors, including municipalities and universities, they can serve as a hub for broader sustainability agendas. They could thus function as a mechanism to facilitate social learning towards sustainability.

In an analysis of German policy documents, Bendix [47] discusses how post-colonial and antiracist theories have started to influence development education in the country over the past decade. The author notes that although critiques had been expressed already in the 1990s, these had long remained marginal. Investigating education in the UK, Chazifotiou [48] examines how policy documents on ESD relate to conditions for teachers' practices and identifies both gaps and incoherencies. Finally, Huckle [49] argues that critical global learning is needed to give young people hope. He contends that this can only be achieved if global learning offers alternatives to current forms of globalization and the inequities it produces. As long as educational systems are not oriented towards such goals, this kind of learning can only take place under various labels such as citizenship, human rights, development, or environmental education. Evaluating the UK Global Learning Program, Huckle concludes that while the program's guidance on content and knowledge tends to legitimize the status quo, the elements of the program that concern skills are more promising.

\subsection{Research on Formal Primary and Secondary Education Contexts}

Research in this area has examined diverse issues, ranging from curricular content to student learning outcomes, student motivation or leadership at school level and forms of collaboration with actors outside the schools.

Schell-Straub [50] describes a German experience in developing mathematics education for global justice, helping secondary school pupils understand complex interlinkages by working with modeling. Béneker, van Dis, and van Middlekoop [51] compare the "world-mindedness" of young people in the Netherlands attending regular schools and those attending international schools. Their results indicated that students at international schools were more "world-minded". The subject geography in regular schools tended to aim for learning about global issues and perspectives, whereas in international schools, the subject also included learning for a global perspective.

Acknowledging that most research in the field has focused on competences and disposition, Maguth and Yang [52] investigate how world history content from curricula in the US and China compare to the SDGs. They examine content standards with respect to SDG 5 on gender equity and find little alignment, concluding that the SDGs could be used to revise content standards in curricula. In a description of ESD programs in India, Bangay [53] observes that co-curricular or extra-curricular learning activities that are not perceived as contributing to school performance have little chance of engaging students. At the same time, he underlines the tension between education for individual purely academic outcomes, and collective outcomes of environmental change.

Focusing on both practice and organization at school level, Bennell [54] examines the role of leadership for education for sustainable development and global citizenship (ESDGC) in primary schools in Wales. Among the forms such education takes, she mentions partnerships between UK schools and schools in the global South. Bennell's findings suggest that personal engagement of head teachers and staff was important. The schools collaborated both with local organizations and through international partnerships. Inviting international visitors was a further aspect mentioned. There were considerable differences in how confident teachers felt about teaching ESDGC, and variation in the types of support the schools offered to their teachers.

\subsection{Research in Further and Higher Education Contexts}

Publications grouped under this theme investigate institutional drivers for GLSD in higher education, funding issues, and the capacity needed to successfully include GLSD in programs. Specific examples of successful programs and initiatives are also given. 
Bentall et al. [13] analyze global learning experiences in UK further education colleges. The authors discuss that the one hand, there is a need for stronger national policy on global learning to go beyond individual initiatives, but that on the other, such initiatives depend on the enthusiasm and commitment of both students and college staff. According to Bentall et al., these may be lost if global learning for global challenges is mainstreamed throughout the curricula. Additionally, local conditions vary, and not all colleges and staff are equally well equipped to teach these issues. Significant factors identified by Bentall et al. were existing overseas partnerships, college structures, senior management support, the personal experience of teachers, staff understanding of global learning, student career choices and sense of their future direction, education maintenance allowance, syllabus requirements and global learning resources, time, and help for teachers.

In a South African business school setting, Sewchurran and McDonogh [55] discuss the issue of how personal transformation of business executives is necessary to support social justice and sustainability. They continue to explore the implications of notions of authenticity and experience for management theory and education in a world characterized by complexity and uncertainty. Fuertes et al. [56] report on how projects on sustainable food are used in the context of a degree program on early childhood education at the international university of Catalunya, including issues of values and ethics. Fuertes et al. stress the value of working with real-world problems and describe how, in the investigated program, a complex question, problem, or challenge serves to drive the learning processes in an integrated manner. Pickford and Ellis [57] describe a collaboration between a local council, a private recycling provider, and the Global Dimensions specialism of a university primary school teacher education program to create an education center for schoolchildren.

A study by Decker and Hawkins [58] investigated global learning and development programs run by North American members of the Council for Christian Colleges \& Universities. The study focused on long term programs and partnerships designed to reduce poverty and promote social progress. Decker and Hawkins found that forms include study trips, study abroad, or student exchange programs, service learning, and partnerships or collaborative action research. The main driver for such programs was a sense of social justice at a global scale. However, respondents also expressed concern that motivation could be alleviating a guilty conscience, and that questions perceived as political might be avoided. Funding of the programs was also a frequent concern.

Moraes [59] presents results from interviews with ten UK academics working with internationalization on their understanding of the term "global citizenship". She argues that the concept is a floating signifier, which takes on different meaning depending on the context. The interviewed academics expressed a wide focus, including the tension between a unified global effort and maintaining pluralism and the driving role of economic agendas. In the editorial [60] to an Open University journal issue on challenges and opportunities offered by distance learning, the Open University Vice Chancellor Peter Horrocks is interviewed on his vision for the future. He points to the ability to deliver distance education across the world at scale, building human capacity, communities of learners, and social learning, with an iterative and collaborative model that is available to learners globally throughout their lifetimes. The main obstacle to this strategic vision for global learning is, according to him, funding, since to be accessible worldwide, Open University resources would have to be funded by UK student fees.

\subsection{Social Learning and Learning Outside Formal Education Contexts}

Much of the work in this theme concerns NGOs' action locally, or their collaboration within wider networks. Research examines both the potentials of such action, and the various practical challenges it entails, including reliance on volunteers, diverging agendas and priorities, or need for a shared language of communication. One study measured the extent of children's self-identification as global citizens without connection to any organized formal or informal learning setting. 
Various forms of social learning are particularly important in view of achieving rapid societal transformation. In previous theoretical work, Waddell [61] contends that global collective action for sustainability can be driven by global action networks (GANs), which are civil society initiated multi-stakeholder arrangements that aim to fulfil a leadership role for systemic change in global governance for sustainable development. Waddell, McLachlan, and Dentoni [62] summarize the principles behind how GANs can address "wicked problems" and achieve systemic transformation, inviting the agro-food industry to engage in a network for global learning comprised of academics partnering with business and other stakeholders.

In a significant study, Feola and Nunes [63] discuss the possibilities and obstacles to bottom-up innovations for climate change adaptation and mitigation, within the framework of sustainability transition theory, looking at the case of the Transition Movement across twenty-three countries. The diffusion of local innovations is connected to local-global learning processes. Unique local experiences can be applicable and relevant to other local contexts. The study concludes that grassroots innovations are the result of local experimentation, and do not necessarily correspond to a consensus concerning imagined futures. Since grassroots innovations typically rely on volunteers, the reach of such innovations is limited. Networking with other local or global actors, in particular other grassroots innovations, can support diffusion. However, geographically isolated transition initiatives are more at risk of being discontinued, even when they are virtually connected online. Local clustering of initiatives therefore supports grassroots innovation processes.

Treating another crucial issue to GLSD, Naleppa and Waldbillig [64] describe the insights gained over 12 years' experience of a staff exchange program between a US and a German NGO without external funding. Naleppa and Waldbillig emphasize the importance of continuity and working in the long term to build trust, since it is difficult to share deeper issues and help each other solve problems until a relationship is well established [64] (p. 896). Naleppa and Waldbillig stress that traveling abroad and hosting supports learning experiences. The issue of having a shared language for collaboration is also mentioned.

Balls [65] studied the ESD work of local and international NGOs in Vietnam. ESD is not part of education curricula in the country, but ESD activities are supported by Vietnamese policy on climate change and environmental challenges. In Vietnam, such projects tend to focus awareness raising rather than advocacy. Although some ESD activities involve schools, the majority are informal educational activities conducted by NGOs. Among the forms such work takes is university students volunteering for local or international NGOs.

Sheehan and Laitinen [66] describe an online youth leadership training program that started in 2008 to support young community activists across the globe. Among issues raised in the evaluation were lack of internet connection in rural areas and problems in understanding "global time". Dong [67] explores how Chinese migrant children are inspired by the international scout movement to expand their skills and gain greater confidence, even without direct interaction with children from other countries. Aubrey [68] describes a collaborative social media and theatre project involving young people from the UK, Hong Kong, Australia, and New Zealand. The aim was to explore identity and diversity through education for sustainable development and global citizenship. Although diversity was a strong element of the project, it was considered too challenging to try to involve other languages than English.

Leithead and Humble [69] draw on Davies' et al. [70] conceptualization of global citizenship and have applied the model of Reysen and Katzarska-Miller [71] to assess self-identification of children in Ghana as global citizens. The model assesses normative environment, global awareness, global citizenship identification, intergroup empathy, valuing diversity, social justice, environmental sustainability, intergroup helping, and responsibility to act on global issues. They found that Ghanaian children living in informal settlements strongly identify as global citizens according to the criteria of this model, 
despite the fact that they do not receive global citizenship education. Leithead and Humble conclude that the notion of global citizenship is not necessarily elitist or Northern-centric.

\subsection{North-South Relationships}

Publications grouped under this theme treat both structural issues at the level of relationships between countries, institutions, and populations, and the various forms of activities that aim to support GLSD. The latter include partnerships between educational institutions with online contacts or exchange of students and staff, study abroad programs and field placements, as well as international volunteering.

Sriprakash, Tikly, and Walker [72] underline that although global sustainability initiatives such as Agenda 2030 ostensibly aim at reducing inequities globally, racism is seldom addressed. International development efforts thereby consolidate racist structures and practices. While educational research typically considers how unequal global power relationships affect opportunities for dialogue between communities of learners, Tsai and Hong [73] investigate these issues at national levels. The study deals with the concrete issues of impacts of globalization on low-income nations, and how island communities can drive their own agendas of sustainable development to benefit local economies, rather than being exploited. The study summarizes outcomes from a geographical conference on this topic, with examples from various contexts. Liu and Liang [74] discuss mechanisms of technology transfer in China as a strategy to support clean energy innovation and as a form of global learning for sustainable development. The point is important, since global action for sustainable development is not only shaped by networks and capacity of individuals, organization, or communities, but largely depends on access to and control over key technologies, with the global inequalities in this respect.

Riitaoja et al. [75] investigate opportunities and limits for collaborative learning and knowledge building in the context of a North-South-South higher education collaboration. The collaboration involved student and teacher exchanges, an online course, an intensive course, network meetings, and administrative visits over a four-year period. Content and learning outcomes focused cultural awareness. Despite ambitions to move beyond existing paradigms and deepen epistemological reflection, making progress proved difficult within the context of this collaboration.

As an example of successful HE partnerships, Heto, Odari, and Sunu [76] analyze the case of an exchange program between the University of Enkare, Nyrobi, and Soka University in Japan that has existed since 1988 and which aims at fostering global citizens. They highlight the strong ethos of Soka University and efforts made to promote interaction and mutual understanding between students as factors of success. In another example of North-South collaboration, Jones [77] argues that urban planning pedagogy should include attention to global challenges in line with the SDGs. The article describes an example of international studios in informal settlements held yearly by an Australian university in collaboration with an Indonesian university, which is recognized by UN Habitat as an example of a solution contributing to sustainable development in cities.

Based on the experiences of a global professional learning community involving schools from Wales and Zanzibar, MacCullum and Salam [78] argue for the benefits of such networks in supporting global education programs in Southern and Northern schools. Strengths of the network MacCullum and Salam investigated include a structure that supports continued professional development, leadership development, re-evaluation of its own structures, sharing and implementing practices, and materials in the participating schools. Further key points raised in the study include enabling reflective professional enquiry; openness, networks and partnerships; including different categories of staff in the network; and mutual trust and support.

In the context of developing a Global Learning Partnership for Universitas21 and their partner universities that can address SDGs, Lees and Webb [79] make a systematic review of the effects of international field placements in the context of programs for students in the health professions. They conclude that field placements enhance cultural awareness 
and cultural knowledge among the students. However, students and academics from the host countries are, according to Lees and Webb, seldom involved in the collaborative learning model. They recommend involvement from host countries to improve outcomes and increase equity.

Studying abroad is considered to be a practice that supports global learning. However, Bikos, Manning, and Frieders [80] point to inequities in who gets the opportunity to participate in such programs, as well as to outcomes that do not match the expectations. Their study investigates US student perceptions before leaving for a study abroad period. Student motivation included personal growth, career development, contributing to the greater good, and improving country and cultural knowledge. Bikos et al. recommend support to reduce inequities and resources available to students before departure. They also recommend alignment of content in their regular program to offer an incrementally graded global learning experience.

Diprose [81] discusses the opportunities and pitfalls for development education in the context of international volunteering and examines experiences from a UK program. The study critically examines the ways international development NGOs in the global North gear their projects to match the personal development needs of the volunteers, rather than addressing concerns in the places they operate. Diprose uses the term "development education" as an umbrella term to cover education for values in a globalized world, and her arguments thus pertain to the objectives and debates concerning global learning. She follows Hanson [82] in arguing that participation in international development NGO projects offers opportunities for transformative experiential learning and critical reassessment of values, as well as building solidarity by giving people possibilities to form connections across different geographical locations [83]. However, Diprose stresses that such learning does not occur without structured support and facilitation. Framing the global South as a "training ground" for Northern volunteers additionally poses ethical questions [84].

A study by Scheinert, Guffler, and Polak [85] investigates to which extent the German international volunteer program weltwärts (towards the world) aligns with and contributes to the SDGs, in particular SDG 4.7. Findings indicate that the program aims to promote gender equality and contribute to "development-related information and education work in the spirit of 'global learning'". Returnees from the program are expected to act as multipliers for development education in Germany. Despite inclusive aims, participants in the program tended to have stronger socioeconomic backgrounds, and minority groups were underrepresented among departing volunteers. Competences increased among participants in the following areas: language skills, the returnees' ability to put themselves in the perspective of people from the host country, and empathy. No significant changes were found in global identity or attitudes towards social diversity. The level of civic engagement did not change among returnees but was to a larger extent oriented towards development work and issues after the program. Importantly, the study pointed to learning among parents and friends of the volunteers, who show increased knowledge about the volunteer's host country, and increase positive attitudes and empathy towards people in the host countries.

\section{GLSD against the Background of Debates and Trends in ESD}

Debates and trends in GLSD have followed many of the more general trends in ESD (see Figure 2). The years following Rio witnessed a reflection on competences needed in sustainable societies, and how to teach them. The reflection was initially oriented towards "action" and to some extent vocational skills connected with reducing environmental impacts, but increasingly also included the question of individual and societal change. Thus, certain strands of research focused the question of how to move from purely intellectual knowledge to emotional engagement and a willingness to change personal behavior. Yet other areas of research dealt with teacher education for ESD, whole school development, or the question of teamwork between teachers of different subjects to encompass both natural and social science dimensions of sustainability. Today, certain strands of ESD research are 
investigating how to change our perception of the world, by shifting the status given to non-human forms of life [86-88].

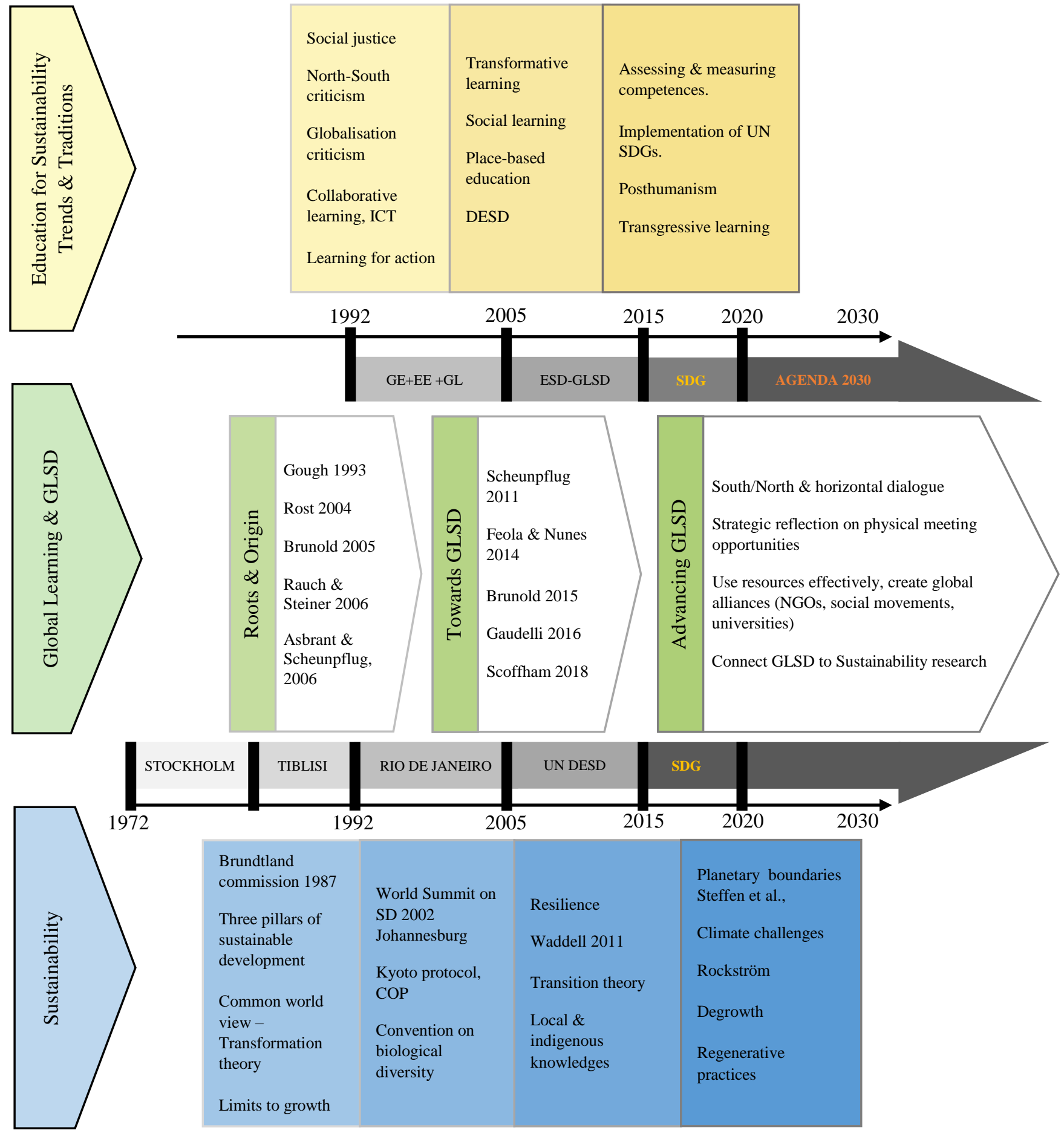

Figure 2. Overview of how discussions in the field of GLSD relate to debates in ESD and sustainability research.

Compared to research oriented towards individual action, relatively little research in ESD has investigated global economic mechanisms or issues of collectively organized action, although there has been a debate on globalization and post-colonial global power structures $[8,24,42,89]$. In the years since Rio, ESD research has also emerged in a variety 
of other directions connected to sustainability challenges, such as higher education for sustainable development (HESD), local and indigenous knowledges, challenge-based learning, science education using socio-scientific issues, place-based education, or the role of outdoor education and contact with nature [7,90-92]. The knowledge that children and young people were supposed to learn in the frame of ESD included an understanding of the interconnectedness of various natural and social phenomena. Pollution is not confined by national borders: what people do in any part of the world has impacts on lives of people in other places. ESD also included the dimension of empathy and solidarity across national borders that was a central element of the Rio vision [1,2].

Global education aims to support both individual and collective competence to act in the name of worldwide solidarity [93]. Thus, numerous researchers approached ESD from the perspective of (global) citizenship education, geography, or intercultural education. Nevertheless, the emphasis within ESD has remained on local action and how education for sustainability could be integrated and implemented in the curricula of national formal education systems. Scheunpflug [94] sees global learning as a guiding principle that should be incorporated in all school subject matters, to prepare for action. The issue is problematic to the extent that assessment and subject-oriented schooling can constitute obstacles to building necessary competences and knowledge capability $[38,45]$. For instance, systems create a tension between assessing individual success and time devoted to collaborative efforts for the common good [53]. Research in Taiwanese schools suggest that the subjectdominated and exam-driven educational climate is not compatible with transdisciplinary learning aims of ESD [95]. Furthermore, in a study of four school subjects in the UK and Germany, Bourn [96] observed that global learning in all the examined four subjects was "perceived as being outside the core elements of the subject" ([96] p. 6). There is thus a risk of fragmented understanding of GLSD concerns when they are spread over school subjects with other primary aims or assessed according to criteria designed mainly to facilitate standardized measurement.

The notion of "preparing for life" (cf. art. 29 of the Convention on the Rights of the Child) that is found in formal education separates the period of passively learning during school, from a supposed period of action situated in the future. A problem with this notion is that it frames "knowledge" as something pre-existent, that is acquired by learners and can subsequently be used and applied. At a time when future conditions are difficult to foresee, and new solutions are urgently needed, learners need to build "knowledge capability" [97], (see also Holdsworth and Thomas [98]) and learn to collaboratively devise functional and sustainable solutions in situations where no ready-made answer exists. Scheunpflug and Asbrand [14] discuss global learning against the background both of globalization and the idea of realizing justice through development, warning against the instrumentalization of education for political goals. They argue that the central aim must be to prepare learners for a world of increasing uncertainties and complexity. Scheunpflug [99] further contends that core competences in global learning include the ability to:

“... understand and critically reflect global interdependencies, own values and attitudes, develop own positions and perspectives, see options, capability to make choices, to participate in communication and decisions within a global context." [99] (pp. 33-34)

The notion that education is about "fostering sustainable values, attitudes, and behaviors among the next generation of global citizens" ([20] p. 1) was already expressed by Gro Brundtland in her introduction to "Our Common Future" [3] and has been pervasive in the literature. However, the idea that knowledge about sustainability challenges would suffice to ensure responsible behavior and action has been criticized [27,98], and several studies point to the limited commitment to sustainability produced by education [100-102]. A succession of "next generations" have become adults since 1987, while the challenges the planet is facing have grown dramatically, and no substantial progress has been made in changing the structural conditions driving this trajectory. Clearly, awareness and knowledge are important, but insufficient to achieve a paradigm shift. While societal change may be achieved through shifts in values among the next generation, framing education 
as preparation for future action neglects the important issue of how values can change sufficiently rapidly in the present generation to avert disaster. Without space to engage in meaningful action [18], learners have limited opportunities during their education to develop the necessary competences, social connections, and experience required to act effectively [103].

The bibliometric review by Hallinger and Chatpinyakoop [20] shows that Barth et al., 2007 [23], and Wiek et al., 2011 [21], are among the most cited publications, indicating a particular interest for competencies in HESD. Research has underlined, however, that GLSD and ESD are not just about content and competencies, but also very much a matter of teaching pedagogies. Jickling and Wals [6] thus contrast authoritative pedagogies involving compliance and conditioning with participatory pedagogies that stress active citizenry and social learning. They further contrast a transmissive paradigm that is predetermined, prescribed, and closed with socio-constructivist transformative learning that is co-created, socially critical, action-oriented, and open. This has considerable consequences for sustainability education generally, since assessment systems are based on authoritative transmissive education, where conformity to predetermined learning outcomes can be measured (see Scoffham [38]).

In a transmissive pedagogical paradigm [7,98], children and young people shape their identities and self-perception as being powerless and simply learning to receive information and faithfully execute instructions. They are drilled to compete against each other to achieve personal success, rather than learning to cooperate for collective action [53]. A focus on testing and performance not only deprioritizes sustainability education compared to other learning objectives, but also discourages collaboration and an ethic of environmental and social care $[49,104]$. We therefore wish to argue that global learning for sustainable development can only be achieved through coupling knowledge about sustainability challenges with learning to act collectively and contribute to societal transformation.

According to Rost [105], knowledge in the field of global development processes is characterized by its high level of complexity and can best be met by a system-oriented approach. The ability to understand and deal with global systematic interconnections is therefore the core competency and should be supported by knowledge from several scientific disciplines. It follows that an interdisciplinary knowledge structure is a basic requirement for learning in this field. Rost further underlines the significance of system thinking competency, valuing competency and shaping/influencing competency in global learning for sustainable development. Fazey et al. [103] stress the value of participatory approaches, as second-order transformation research. This means that they involve experiential learning, that is, not only using systemic thinking to reflect on underlying assumptions in "producing evidence about, and action for, solutions", but also learning from the action" [103] (p. 65). According to Fazey et al., such processes "follow a prescriptive and normative logic and actively seek to be part of the process of fulfilling societal needs in fundamentally new ways" [103] (p. 65).

\section{Limitations of Strategies Implemented Since Rio}

The reasoning behind the Rio [1,2] vision for how societies could transition from business-as-usual towards greater sustainability has had considerable consequences, not only for political action, but also for the orientation and content of education for sustainability. As outlined above, information, knowledge, education, and awareness were all seen to play a key role in societal transformations globally. As we have seen, citizens were expected to contribute to the process by accepting changes to their habits and lifestyles. Indirectly, citizens could also contribute by supporting sustainable policies through their democratically elected representatives. From a UN perspective, however, increased democracy was a possibly a desired outcome but could not be taken as a prerequisite for sustainability. Almost thirty years later, in Agenda 2030, the word democracy is conspicuously absent from the SDGs, and only indirectly alluded to in Target 16.7: "Ensure responsive, inclusive, participatory, and representative decision-making at all levels", with the indicator 16.7.2 
"Proportion of population who believe decision-making is inclusive and responsive, by sex, age, disability, and population group" [106,107]. Due to a strategic political focus on consensus, any issues of conflicting interests were also downplayed at Rio.

In ESD, efforts were consequently directed towards raising awareness of sustainability issues, strengthening students' scientific literacy, and pointing to concrete actions in their daily lives where they could contribute to a cleaner planet, such as recycling or avoiding littering. The intention was to build among the younger generation a commitment to support implementation of sustainability goals, rather than to question priorities and orientation of policies, or to actively drive for change. Although there was also mention of local and global "action", this was mostly oriented towards "spreading the word" and to gaining adherence to the Rio vision within local communities. However, the assumption that awareness or knowledge would lead to behavioral change does not appear to be warranted [27]. In a study of UK schools, Hunt [108] found that despite far-reaching ambitions, the program seemed more likely to encourage small-scale lifestyle changes and develop a greater interest in global issues, rather than necessarily lead to children's involvement in social action. In those contexts where attempts to "raise awareness" among young people are successful, the result may therefore be disillusionment, depression, and a feeling of powerlessness. Among researchers in education, the following years saw the emergence of a discussion concerning democracy and the normative dimensions of sustainability, ensuing in reflections concerning values or conflicts in values.

Gwin and Foggin [109] underline that ESD continues to be dominated by a small set of countries, to the detriment of marginalized and peripheral communities. Core countries not only control content, finances, and standards of educational systems worldwide, but also languages of instruction and research publications. This drives brain-drain from the periphery and offers marginalized communities few opportunities to develop locally relevant education (see also Hatley [36]). Nevertheless, despite the continued dominance of Northern-centric discourse and perspectives in discourse on globalization, development agendas, and global learning, Stromquist and Monkman [89] point to the potential of global learning to support development and share in horizontally approached dialogues. Training and promoting critical thinking could allow young people to identify the underlying causes of global challenges. Moving beyond a paradigm of one-way transmission of predetermined content and agendas, GLSD needs more than ever to have the capacity to engage and remain credible for those who are engaged in it. Not only is a reconsideration of global power balances within the UN system more urgent than ever [110], but we wish to argue that our attention must be placed on strengthening movements, initiatives, and networks that support GLSD. This means supporting the ability to organize learning that is relevant to local concerns, but also acquiring the skills for action and seeing pathways to actually change a status quo that at a global level has already led to collapse. Without avenues for action, increased awareness will only lead to pessimism and disengagement $[49,111,112]$, while blatant inequities feed frustration that cannot be channeled into constructive action.

Over the past three decades, the UN has consistently sought to build on the ideas that were initially presented at Rio, with initiatives such as the Millennium Goals, the UN Decade of Education for Sustainable Development [22], and the current Agenda 2030 [106]. However, while the challenges highlighted at Rio appear more pressing than ever, the conditions for collectively addressing them at a global scale have substantially deteriorated. In retrospect, it is clear that the reasoning behind the notion that sustainable development could be achieved in the intersection of the social, economic, and environmental domains was flawed. Attempts to "decouple" growth and environmental impacts through efficiency has not resulted in a decrease of emissions or other environmental impacts, while tighter environmental regulation in certain "developed" nations has accelerated the tendency to locate heavily polluting industries in the "developing" world. Nevertheless, the figure of three intersecting domains of sustainable development—originally intended to facilitate a consensus for action and avoid issues where conflicts of interest might arise-has persisted 
in the literature until this day. Today, the UN development agenda remains focused on economic issues [5].

With respect to global warming and limiting greenhouse gas emissions, the Kyoto Protocol was adopted in 1997 and entered into force in 2005. The United States never ratified the protocol and Canada withdrew in 2012. The Kyoto Protocol has been superseded by the Paris Agreement of 2015. Although some action on emissions has been set in motion, it is unclear if the parties to the Paris Agreement will achieve the targets they have set with respect to global warming, while the latest climate research suggests that warming dynamics are both much quicker and more devastating than earlier assumed. Prospects concerning other planetary boundaries [113] are equally bleak [114-116].

Already Gro Brundtland [3] deplored the loss of multilateralism that had occurred since the decolonialization process of the post-war period. The further weakening of UN structures [117] and mechanisms of international law that are suggested by the current lack of global commitment with respect to greenhouse emissions and environmental targets is mirrored in other domains. To the extent that Agenda 2030, education for sustainable development, and global learning for sustainable development all rely on the adherence to fundamental values underlying multilateralism and the UN system, we believe that a reappraisal of certain of the assumptions behind the Rio agenda $[4,5,9,10]$ is necessary. We also wish to argue for the urgency of considering the implications of these developments for education and sustainability activism.

\section{Where Do We Go from Here?}

Work with different approaches, collaborations, debate, and research over the past decades have offered valuable information that can help with strategic choices on directions to pursue in GLSD today. However, many emerging challenges are still uncharted territory. Based on our review and current developments, we would like to point to two interrelated areas we feel need particular attention: what is the role of personal experience and contacts in forming knowledge and capacity for rapid global sustainability transitions, and how do we build commitment, credibility, and discernment in the "post-truth" era?

Like other strands of ESD, global learning for sustainable development (GLSD) was initially largely based on the Rio vision and definition of "sustainable development" as moving forward incrementally within the "win-win" intersection of the economic, social, and environmental spheres. Within this approach, the emphasis was placed on local-global interrelationships, that is, the specific question of how to achieve understanding, empathy, engagement, collaboration, and exchange of experiences across national borders, enabling the shift to sustainable development. While this dimension of the Rio agenda [1,2] was also present in ESD, it became the particular focus of GLSD. In their review of various strands of ESD, Wals and Kieft [7] summarize GLSD as "developing learning on the uncertainty of knowledge, in the process of establishing links between everyday problems, global processes, and lines of conflicts" (p. 20). They stress that most ESD activity is life-long and takes place within non-formal and informal learning settings, often driven by NGOs. These processes fall under the broader notion of "social learning". For Wals and Kieft, this involves creating a "learning system" that puts "differences to use", where people learn from each other and collectively become more able of dealing with challenges ([7], p. 37). Collaborating across contexts thus does not only enable mutual understanding and solidarity, but provides a wider range of perspectives and experiences, which is needed to deal with the complexities and uncertainties of global sustainability challenges today.

GLSD drew on previous discussions and experiences in movements aiming to ensure world peace, as well as movements of emancipation and solidarity striving to achieve global justice. Earlier efforts for global citizenship had largely relied on printed textbook materials, possibly supplemented by films and televised documentaries. Only small numbers of young people could benefit from direct experiences and engagement through "global" schools, student exchange programs, volunteering, study trips, camps, or conventions. However, in the late 1990s, the internet was starting to become widely accessible, which 
presented entirely new ways of connecting and communicating across national borders. While continuing to reflect on the potentials of direct personal experience, in both GLSD and other areas of education, a significant amount of research was directed towards the possibilities opened by the new ICT technologies in "global classrooms" [118] as well as issues of immersive and explorative learning through virtual realities, gaming and computer simulations.

It is all too easy to treat knowledge, knowledge sharing, and knowledge development as abstract disembodied entities. However, learning "how to" is eminently embodied. All of the competencies, skills, bodies of knowledge, and capacities required for sufficiently rapid, radical, socially and globally just, agile, wise, and foresightful planetary sustainability transitions require long practice and low-stakes opportunities to try out and experiment. Sustainability transitions are based on collective action, but the learning does not take place in abstract "populations"; it is carried by engaged individuals and groups or networks of specific people. This supposes that these individuals, groups, and networks can actually work in a continuous manner to gradually, over time, build the necessary knowledge, experiences, and capacity. Besides funding and physical or organizational resources, transnational networks build on trust, mutual respect, and deep understanding of the diverse contexts people live in. These are all difficult to achieve without opportunities for face-to-face meetings and exchanges allowing extended periods of work [63], while also in formal education settings, personal meetings, exchange, and study trips play an important role [119].

Much of the pedagogical reflection for GLSD has been devoted to how to achieve a sense of connectedness, personal life-long commitment, and a sufficiently deep and nuanced understanding of how other people live, without a foundation in personal experiences and relationships. In a study in the UK, Hunt [108] found that most pupils' active commitment in global learning related to their interactions with school linking programs overseas and fundraising activities. Establishing concrete connections thus plays a role in formal education settings. However, the strongest forms of global learning take place as a result of study visits, physically attending meetings with delegates from various countries, or longer periods of exchange with partners in an international network [34,120]. Such activities demand considerable resources, at the same time that reducing travel is crucial for living within planetary boundaries. GLSD is thus exposed to similar constraints as other initiatives for intercultural education, mobility, or internationalization.

Travelling and spending time in other countries requires money, as well as administration to organize such meetings, the ability to take time off other activities, arranging and getting visas, etc. While there are numerous arguments for physical meetings and experiences from visits to other countries [70], as opposed to exclusively online contacts, there is no doubt that this requires resources, as well as the need to consider environmental impacts of travel as such. Other significant considerations are the inequities in who can participate in these exchanges [80], whose voices are heard, and the frequent framing of "development" as being a one-way flow of expertise and assistance from the North to the South, where Northern participants may gain experience and personal growth in exchange.

To build, maintain, and develop capacity in transnational collaboration networks [61,63] also demands commitment and institutional support. To justify the collaborative costs that collaboration entails, it is therefore important to carefully consider the objectives of such collaboration and pay sufficient attention to the forms it takes. For instance, research has shown that when young people from the global North spend time abroad or engage in volunteering projects, the experience can be transformative, but in many cases experiences are shallow $[75,79,81]$, and work may be framed within a patronizing notion of "aid". Similarly, when students from the global South study at Northern universities or schools, they are seldom offered opportunities to express their own concerns or engage in deep dialogues. To yield fruits, such initiatives need persistence and continuity [94].

There are also other reasons why GLSD goals of connectedness, commitment, and understanding are getting progressively more difficult to achieve. On the one hand, GLSD 
efforts are competing for attention with the entertainment industry, social media, aggressive marketing, and information "overload", or efforts to simply survive in economies affected by austerity, corruption, automation, warfare, climate stress, and natural disasters. On the other hand, extreme right-wing ideologies have been extraordinarily successful these past decades in spreading messages of fear, intolerance, hate, and racism.

There has always been an inherent tension between the "normative" aspect of ESD and the common mission of formal schooling systems to be "neutral", simply transmitting "objective" knowledge. Clearly, the consensus in any country on what is acceptable non-controversial curricular content is defined by local traditions, as well as by various political or commercial agendas. However, while it is easy to argue that the status quo is not sustainable, and merely serves to cement behaviors and stances that are driving planetary disasters, it is not equally easy to suggest alternatives. Merely advocating "critical thinking" [121] is not enough. Ideally, citizens should have sufficient knowledge about facts to make informed choices, but this is becoming increasingly difficult. Not only is grasping the complexities of global interrelationships highly challenging for young people, but the rapid changes and new situations that are appearing make the task equally challenging for the scientific community. Additionally, in the "post-truth" era, young people have to understand the dynamics of deliberate disinformation campaigns and attempt to identify reliable sources of information against a background of sensationalism, propaganda, as well as well-intentioned but far-to-rapid conclusions. Here, GLSD can play an important role, by giving access to a wider range of perspectives, experiences, knowledge bases, and insights, beyond the fragmented and commercialized "globalized" media landscape [16].

\section{Conclusions}

Like a number of reviews focusing on education for sustainable development research literature [4,17-20], our review shows an increase in publications over the investigated period. The limited number of publications included in our review of global learning for sustainable development does not allow us to draw statistically significant conclusions, but the pattern of publications in English accessible through major indexed databases shows tendencies similar to the reviews in related fields. Researchers based in countries of the global North and particularly countries where English is spoken clearly dominate the field. According to an overview in the Global Education Digest 2020 [30], the US, UK, Australia, and Canada overwhelmingly dominate publications on global education, while the US has a far greater number of publications than other English-speaking countries in that field.

The focus on underrepresentation of Southern countries partly obscures the gaps shown by the various reviews in publication from countries classified as "developing" according to UN criteria [122]. Small low-income countries are absent, while a few large, geopolitically significant, and economically relatively powerful countries are left to represent perspectives from the global South. As in reviews on ESD and HESD literature, topics, types of studies, and theoretical perspectives are relatively diverse, but across the field, reference is made to the large international policy documents (such as Agenda21 [2], the Millenium Goals [123], and the SDGs [106,107]) and their targets concerning sustainable development (see timeline in Figure 1). By contrast, the reviewed literature makes little reference to research from the wider field of sustainability studies, or to diverse international reports and agreements on issues such as biodiversity, environmental degradation, farming and land injustice, or climate scenarios.

While the Brundtland report [3] and the DESD [22] in some sense opened schooling and education to the pressing sustainability concerns of the world, the silo structure of the SDGs risk reducing the role of education for sustainability to producing "quality education". This risk is increased by the choice of indicators to track progress, notably the insistence on digitalization. Kuntsman and Rattle [124] analyze the technocratic character of discourses on sustainability and in particular criticize the belief that solutions are offered by digitalization and ICTs (see also Hall [34]). ICTs offer possibilities of global dialogue and exchange, but both information technology and media coverage also present difficulties 
in understanding decontextualized fragments of information. The question of how such dialogue can be pursued democratically therefore requires close attention.

As an outcome of Rio, GLSD was both driven by the enthusiasm of this summit and marked by its flaws. Crucially, it avoided the question of funding and structural drivers, assuming that all nations and all actors were in agreement to support these efforts. Global education (GE) was introduced in the 1960s [8] and from 1974 an international environmental education program was launched by the United Nations Environment Program (UNEP). This program was already at an early stage criticized for perpetuating a neocolonialist discourse in environmental education [125], rather than promoting genuine international cooperation-a stance which has affected the very meaning given to the notion of sustainability.

Although research on GLSD has not seen the expansion that ESD literature has, the need for global collaboration on sustainability issues is more urgent than ever. There is no time to wait for new generations to acquire the competences needed for sustainability transitions. GLSD therefore needs to focus not only on initial education but increasingly on non-formal and adult learning. Fazey et al. [103] contend that "second order transformation research" is required to achieve a broader societal shift [103] (p. 63). Knowledge creation can therefore not be conceptualized as separate from politics and decision-making processes. To achieve transformation, GLSD cannot avoid the underlying political issues driving inequity and unsustainable development. From Figure 2, it appears that both ESD and GLSD are only marginally informed by recent developments in sustainability research, such as transition theory [126]. Greater attention to advances in sustainability research, including theories of change, would be required. Since funding and resources are scarce, we recommend searching alliances, such as the collaborations suggested by Waddell [61] and Feola and Nunes [63].

Already in the 1990s, critical voices such as Gough [125] pointed to the effects of an unequal global landscape on environmental education. Several decades later, these concerns are still warranted. To conclude, it is high time to priorities South-North and horizontal South-South dialogue in the field of global learning for sustainability, to ensure that what is called development does not serve to export environmental costs or further aggravate inequities.

\section{Limitations}

The choice to include almost all the publications found in the search means that the review is not limited by a particular definition of GLSD and can instead offer an overview of the different understandings and directions research has taken in the field. This reduces the bias in selection of publications that would come if we had included or excluded publications based on criteria of relevance deriving from a strict definition. However, basing our review on publications found using the search terms "global learning" AND "sustainability", respectively, "sustainable development" also means that literature using other terms to designate concepts pertaining to the field is not included.

The choice of using English search terms and limiting the review to publications in English produces a bias in favor of publications coming from English-speaking countries and involving English-speaking researchers. However, a similar dominance of Englishspeaking countries in GLSD research is found in international scientific publication generally $[127,128]$ and has been noted in bibliometric reviews of ESD research. From the publications found in our search that involved researchers from other language areas, it appears that different traditions, perspectives, and approaches have developed in, for instance, the German- or Spanish-speaking areas (see, e.g., [12,14,18]), which the present review is unable to capture or discuss.

As an avenue for future research on GLSD, the Academic Network on Global Education and Learning (ANGEL) bibliography on global education [129] lists publications in English, French, German, Italian, Portuguese, and Spanish, and can serve as a point of departure for studies on GLSD in these languages. 
Author Contributions: Both authors contributed equally to the conceptualization, investigation, earlier research, methodology, and writing of this article. Conceptualization: B.N. and H.A.; investigation: B.N. and H.A.; earlier research: B.N. and H.A.; methodology: B.N. and H.A.; writing: B.N. and H.A. Both authors have read and agreed to the published version of the manuscript.

Funding: This research received no external funding.

Institutional Review Board Statement: Not applicable.

Informed Consent Statement: Not applicable.

Data Availability Statement: Not applicable.

Acknowledgments: We would like to thank the Middle East in the Contemporary World Strategic Research Area (MECW). A special thanks to Region Skånes Miljöfond (Environmental Fund) and Studies in Science, Environmental and Mathematics education (SISEME) at the University of Malmö.

Conflicts of Interest: The authors declare no conflict of interest.

\section{References}

1. UN. Resolutions Adopted by the Conference. A/CONF.151/26/Rev.1. In Report of the United Nations Conference on Environment and Development, Rio de Janeiro, Brazil, 3-14 June 1992; United Nations: New York, NY, USA, 1993; Volume I. Available online: https://www.un.org/esa/dsd/agenda21/Agenda\%2021.pdf (accessed on 26 November 2020).

2. Agenda 21. United Nations Sustainable Development. In Proceedings of the United Nations Conference on Environment \& Development, Rio de Janerio, Brazil, 3-14 June 1992. Available online: https://sustainabledevelopment.un.org/content/ documents / Agenda21.pdf (accessed on 26 November 2020).

3. Brundtland, G. Our Common Future (The Brundtland Report). In World Commission on environment and Development; University Press: Oxford, UK, 1987.

4. Aikens, K.; McKenzie, M.; Vaughter, P. Environmental and sustainability education policy research: A systematic review of methodological and thematic trends. Environ. Educ. Res. 2016, 22, 333-359. [CrossRef]

5. Luetz, J.M.; Walid, M. Social Responsibility Versus Sustainable Development in United Nations Policy Documents: A Metaanalytical Review of Key Terms in Human Development Reports. In Social Responsibility and Sustainability; World Sustainability Series; Leal Filho, W., Ed.; Springer: Cham, Switzerland, 2019; pp. 301-334, World Sustainability Series.

6. Jickling, B.; Wals, A.E.J. Globalization and environmental education: Looking beyond sustainable development. J. Curric. Stud. 2008, 40, 1-21. [CrossRef]

7. Wals, A.E.; Kieft, G. Education for Sustainable Development: Research Overview; Sida Review 2010: 13; Swedish International Development Cooperation Agency: Stockholm, Sweden, 2010.

8. Gaudelli, W. World Class: Teaching and Learning in Global Times; Lawrence Erlbaum Associates: Mahwah, NJ, USA, 2003.

9. Purvis, B.; Mao, Y.; Robinson, D. Three pillars of sustainability: In search of conceptual origins. Sustain. Sci. 2019, 14, 681-695. [CrossRef]

10. Dion, M.A. Typology of Corporate Environmental Policies. Environ. Ethics 1998, 20, 151-162. [CrossRef]

11. Schugurensky, D. The forms of informal learning: Towards a conceptualization of the field. SSHRC Research Network New Approaches to Lifelong Learning (NALL) Wall Working Paper No.19. 2000. Available online: https://tspace.library.utoronto.ca/ bitstream/1807/2733/2/19formsofinformal.pdf (accessed on 26 November 2020).

12. Rauch, F.; Steiner, R. School development through Education for Sustainable Development in Austria. Environ. Educ. Res. 2006, 12, 115-127. [CrossRef]

13. Bentall, C.; Bourn, D.; McGough, H.; Hodgson, A.; Spours, K. Global Learning for Global Colleges: Creating opportunities for greater access to international learning for 16-25 year olds. J. Furth. High. Educ. 2014, 38, 621-640. [CrossRef]

14. Scheunpflug, A.; Asbrand, B. Global education and education for sustainability. Environ. Educ. Res. 2006, 12, 33-46. [CrossRef]

15. Irving, Z.; Yeates, N.; Young, P. What Can Global Perspectives Contribute to Curriculum Development in Social Policy? Soc. Policy Soc. 2005, 4, 475-484. [CrossRef]

16. Barker, T. Moving toward the centre: Transformative learning, global learning, and indigenization. J. Transform. Learn. 2020, 7, 8-22.

17. Grosseck, G.; Tîru, L.G.; Bran, R.A. Education for sustainable development: Evolution and perspectives: A bibliometric review of research, 1992-2018. Sustainability 2019, 11, 6136. [CrossRef]

18. Bascopé, M.; Perasso, P.; Reiss, K. Systematic Review of Education for Sustainable Development at an Early Stage: Cornerstones and Pedagogical Approaches for Teacher Professional Development. Sustainability 2019, 11, 719. [CrossRef]

19. Hallinger, P.; Nguyen, V.-T. Mapping the Landscape and Structure of Research on Education for Sustainable Development: A Bibliometric Review. Sustainability 2020, 12, 1947. [CrossRef]

20. Hallinger, P.; Chatpinyakoop, C. A Bibliometric Review of Research on Higher Education for Sustainable Development, 1998-2018. Sustainability 2019, 11, 2401. [CrossRef] 
21. Wiek, A.; Withycombe, L.; Redman, C.L. Key Competencies in Sustainability: A Reference Framework for Academic Program Development. Sustain. Sci. 2011, 6, 203-218. [CrossRef]

22. UNESCO. UN Decade of Education for Sustainable Development. Links between the Global Initiatives in Education, Education for Sustainable Development in Action, Technical Paper No. 1. September 2005. Available online: https:/ /unesdoc.unesco.org/ark: /48223/pf0000140848?posInSet=1\&queryId=28606f6d-799c-4d08-ab2b-3e2cf223a5da (accessed on 15 March 2021).

23. Barth, M.; Godemann, J.; Rieckmann, M.; Stoltenberg, U. Developing key competencies for sustainable development in higher education. Int. J. Sustain. High. Educ. 2007, 8, 416-430. [CrossRef]

24. Gaudelli, W. Global Citizenship Education: Everyday Transcendence; Routledge: New York, NY, USA, 2006.

25. Peterson, A.; Warwick, P. Global Learning and Education: Key Concepts and Effective Practice; Routledge: London, UK, 2014.

26. Brunold, A.O. The United Nations decade of education for sustainable development, its consequences for international political education, and the concept of global learning. Int. Educ. J. 2006, 7, 222-234.

27. Brunold, A.O. Global learning and education for sustainable development. High. Educ. Eur. 2005, 30, 295-306. [CrossRef]

28. Brunold, A.O. Civic Education for Sustainable Development and its Consequences for German Civic Education Didactics and Curricula of Higher Education. Discourse Commun. Sustain. Educ. 2015, 6, 30-49. [CrossRef]

29. Brunold, A.O. Globales Lernen und Lokale Agenda 21. Aspekte kommunaler Bildungsprozesse in der "Einen Welt"; Global Learning and Local Agenda 21. Aspects of Communal and Educational Processes in "One World"; VS Verlag für Sozialwissenschaften: Wiesbaden, Germany, 2004; p. 47.

30. Choi, J.-K. Play locally, learn globally: Group selection and structural basis of cooperation. J. Bioeconomics 2008, 10, 239-257. [CrossRef]

31. Khazem, D. Critical Realist Approaches to Global Learning: A Focus on Education for Sustainability. Int. J. Dev. Educ. Glob. Learn. 2018, 10, 125-134. [CrossRef]

32. Scheunpflug, A.; Krogull, S.; Franz, J. Understanding Learning in World Society: Qualitative Reconstructive Research in Global Learning and Learning for Sustainability. Int. J. Dev. Educ. Glob. Learn. 2016, 7, 6-23. [CrossRef]

33. Khoo, S.-M. Sustainable Knowledge Transformation in and through Higher Education: A Case for Transdisciplinary Leadership. Int. J. Dev. Educ. Glob. Learn. 2017, 8, 5-24. [CrossRef]

34. Hall, B.W. Information Technology and Global Learning for Sustainable Development: Promise and Problems. Altern. Glob. LocalPolitical 1994, 19, 99-132. [CrossRef]

35. Lang-Wojtasik, G. Transformative Cosmopolitan Education and Gandhi's Relevance Today. Int. J. Dev. Educ. Glob. Learn. 2018, 10, 72-89. [CrossRef]

36. Hatley, J. Universal Values as a Barrier to the Effectiveness of Global Citizenship Education: A Multimodal Critical Discourse Analysis. Int. J. Dev. Educ. Glob. Learn. 2019, 11, 87-102. [CrossRef]

37. Barrow, E. No global citizenship? Re-envisioning global citizenship education in times of growing nationalism. High Sch. J. 2017, 100, 163-165. [CrossRef]

38. Scoffham, S. Global Learning: A Catalyst for Curriculum Change. Int. J. Dev. Educ. Glob. Learn. 2018, 10, 135-146. [CrossRef]

39. Chung, B.G.; Park, I. A review of the differences between ESD and GCED in SDGs: Focusing on the concepts of global citizenship education. J. Int. Coop. Educ. 2016, 18, 17-35.

40. Bourn, D. Education for sustainable development and global citizenship. The challenge of the UN-decade. Zep Z. Für Int. Bild. Und Entwickl. 2005, 28, 15-19.

41. Torres, C.A. Globalization, Education, and Citizenship: Solidarity vs Markets. In Globalization and Education, Collected Essays on Class, Race, Gender, and the State; Torres, C.A., Ed.; Teacher's College, Columbia University: New York, NY, USA, 2009.

42. Andreotti, V. Soft versus critical global citizenship education. Policy Pract. A Dev. Educ. Rev. 2006, 3, 40-51.

43. UNESCO. Global Citizenship Education, Topics and Learning Objectives; UNESCO: Paris, France, 2015; ISBN 978-92-3-100102-4. Available online: https:/ / unesdoc.unesco.org/ark:/48223/pf0000232993 (accessed on 26 November 2020).

44. Vaccari, V.; Gardinier, M.P. Toward One World or Many? A Comparative Analysis of OECD and UNESCO Global Education Policy Documents. Int. J. Dev. Educ. Glob. Learn. 2019, 1, 68-86. [CrossRef]

45. Xiaomin, L.; Auld, E. A historical perspective on the OECD's 'humanitarian turn': PISA for Development and the Learning Framework 2030. Comp. Educ. 2020, 1-19. [CrossRef]

46. Fadeeva, Z.; Mochizuki, Y. Regional Centres of Expertise: Innovative Networking for Education for Sustainable Development. J. Educ. Sustain. Dev. 2007, 2, 229-237. [CrossRef]

47. Bendix, B. Decolonizing Development Education Policy: The Case of Germany. Int. J. Dev. Educ. Glob. Learn. 2018, 2, 147-162. [CrossRef]

48. Chatzifotiou, A. Education for sustainable development: Vision, policy, practices-An open or closed 'doorway' for teachers and schools? World Sustain. Ser. 2018, 197-209. [CrossRef]

49. Huckle, J. Becoming Critical: A Challenge for the Global Learning Programme? Int. J. Dev. Educ. Glob. Learn. 2017, 3, 63-84. [CrossRef]

50. Schell-Straub, S. Mathematics Education Meets Development Education: The Competency 'Mathematical Modelling' Combined with Global Skills and Competencies in a Secondary School Project in Germany. Int. J. Dev. Educ. Glob. Learn. 2013, 1, 7-31. [CrossRef] 
51. Béneker, T.; van Dis, H.; van Middelkoop, D. World-Mindedness of Students and Their Geography Education at International (IB-DP) and Regular Schools in the Netherlands. Int. J. Dev. Educ. Glob. Learn. 2014, 6, 5-30. [CrossRef]

52. Maguth, B.M.; Yang, H. The United Nations Sustainable Development Goals as a Global Content Framework? J. Int. Soc. Stud. 2019, 1, 3-28.

53. Bangay, C. Protecting the Future: The Role of School Education in Sustainable Development-An Indian Case Study. Int. J. Dev. Educ. Glob. Learn. 2016, 1, 5-19. [CrossRef]

54. Bennell, S.J. Education for Sustainable Development and Global Citizenship: Leadership, Collaboration, and Networking in Primary Schools. Int. J. Dev. Educ. Glob. Learn. 2015, 1, 5-32. [CrossRef]

55. Sewchurran, K.; McDonogh, J. The Phenomenon of "Being-In-Management" in Executive Education Programmes: An Integrative View. Int. J. Dev. Educ. Glob. Learn. 2015, 7, 75-88. [CrossRef]

56. Fuertes-Camacho, M.T.; Graell-Martín, M.; Fuentes-Loss, M.; Balaguer-Fàbregas, M.C. Integrating sustainability into higher education curricula through the project method, a global learning strategy. Sustainability 2019, 11, 767. [CrossRef]

57. Pickford, T.; Ellis, L. The creation of interactive activity pods at a Recycling Education Centre. Local Econ. 2015, 30, 370-381. [CrossRef]

58. Decker, A.; Hawkins, G. Global Learning and Development as an Engagement Strategy for Christian Higher Education: A Macro Study. High. Educ. 2016, 5, 263-286. [CrossRef]

59. Moraes, S.E. Global Citizenship as a Floating Signifier: Lessons from UK Universities. Int. J. Dev. Educ. Glob. Learn. 2014, 6, 27-42. [CrossRef]

60. Bell, S. Sustainable distance learning for a sustainable world. J. Open Distance Learn. 2016, 31, 1-8. [CrossRef]

61. Waddell, S. Global Action Networks: Creating our Future Together; Palgrave-Macmillan: Hampshire, UK, 2011.

62. Waddell, S.; McLachlan, M.; Dentoni, D. Learning \& transformative networks to address wicked problems: A golden invitation. Int. Food Agribus. Manag. Rev. 2013, 16, 23-32.

63. Feola, G.; Nunes, R. Success and failure of grassroots innovations for addressing climate change: The case of the transition movement. Glob. Environ. Chang. 2014, 24, 232-250. [CrossRef]

64. Naleppa, M.J.; Waldbillig, A.A. International staff exchange: Evaluation of a collaborative learning partnership. Int. Soc. Work 2018, 61, 891-903. [CrossRef]

65. Balls, E. Analysing Key Debates in Education and Sustainable Development in Relation to ESD Practice in Viet Nam. J. Dev. Educ. Glob. Learn. 2016, 1, 21-37. [CrossRef]

66. Sheehan, M.; Laitinen, J. The Earth Charter Goes Interactive and Live with e-GLO: Using New Media to Train Youth Leaders in Sustainability on Both Sides of the Digital Divide. J. Educ. Sustain. Dev. 2010, 4, 253-258. [CrossRef]

67. Dong, J. Global Learning from the Periphery: An Ethnographic Study of a Chinese Urban Migrant School. Sustainability 2020, 12, 381. [CrossRef]

68. Aubrey, M. CLICK: Arts Education and Critical Social Dialogue within Global Youth Work Practice. Int. J. Dev. Educ. Glob. Learn. 2015, 1, 71-91. [CrossRef]

69. Leithead, J.; Humble, S. How Children Living in Poor Informal Settlements in the Greater Accra Region, Ghana, Perceive Global Citizenship. Int. J. Dev. Educ. Glob. Learn. 2020, 12, 69-83. [CrossRef]

70. Davies, I.; Ho, L.-C.; Kiwan, D.; Peck, C.L.; Peterson, A.; Sant, E.; Waghid, Y. (Eds.) The Palgrave Handbook of Global Citizenship and Education; Palgrave Macmillan: London, UK, 2018.

71. Reysen, S.; Katzarska-Miller, I. A model of global citizenship: Antecedents and outcomes. Int. J. Psychol. 2013, 48, 858-870. [CrossRef]

72. Sriprakash, A.; Tikly, L.; Walker, S. The erasures of racism in education and international development: Re-reading the 'global learning crisis'. Compare 2020, 50, 676-692. [CrossRef]

73. Tsai, H.-M.; Hong, S.-K. Island development: Local governance under globalization. J. Mar. Isl. Cult. 2014, 3, 41-42. [CrossRef]

74. Liu, H.; Liang, D. A review of clean energy innovation and technology transfer in China. Renew. Sustain. Energy Rev. 2013, 18, 486-498. [CrossRef]

75. Riitaoja, A.-L.; Posi-Ahokas, H.; Janhonen-Abruquah, H. North-South-South Collaboration as a Context for Collaborative Learning and Thinking with Alternative Knowledges. Int. J. Dev. Educ. Glob. Learn. 2019, 2, 189-203. [CrossRef]

76. Heto, P.P.-K.; Odari, M.H.; Sunu, W.K. Different schools, different cultures. In Handbook on Promoting Social Justice in Education; Papa, R., Ed.; Springer: Berlin/Heidelberg, Germany, 2020; pp. 583-608. [CrossRef]

77. Jones, P. The case for inclusion of international planning studios in contemporary urban planning pedagogy. Sustainability 2019, 11, 4174. [CrossRef]

78. MacCallum, C.; Salam, I. Making a MEAL out of a Global Professional Learning Community: A Transformative Approach to Global Education. Int. J. Dev. Educ. Glob. Learn. 2014, 3, 31-48. [CrossRef]

79. Lees, J.; Webb, G. A review of the literature to inform the development of a new model of global placement: The Global Learning Partnership. Phys. Ther. Rev. 2018, 23, 40-49. [CrossRef]

80. Bikos, L.H.; Manning, S.B.; Frieders, Z.J. Ready or not here I come: A qualitative investigation of students' readiness perceptions for study abroad/away. Int. Perspect. Psychol. Res. Pract. Consult. 2019, 8, 78-91. [CrossRef]

81. Diprose, K. Critical distance: Doing development education through international volunteering. AREA 2012, 44, 186-192. [CrossRef] 
82. Hanson, L. Global citizenship, global health, and the internationalization of curriculum: A study of transformative potential. J. Stud. Int. Educ. 2010, 14, 70-88. [CrossRef]

83. Crabtree, R.D. Mutual empowerment in cross-cultural participatory development and service learning: Lessons in communication and social justice from projects in El Salvador and Nicaragua. J. Appl. Commun. Res. 1998, 26, 182-209. [CrossRef]

84. Baillie Smith, M.; Laurie, N. International volunteering and development: Global citizenship and neoliberal professionalisation today. Trans. Inst. Br. Geogr. 2011, 36, 545-559. [CrossRef]

85. Scheinert, L.; Guffler, K.; Polak, J.T. International Development Volunteering: An Instrument for Promoting Education in Line with the Sustainable Development Goals? Int. J. Dev. Educ. Glob. Learn. 2019, 1, 4-28. [CrossRef]

86. Schlosberg, D.; Coles, R. The new environmentalism of everyday life: Sustainability, material flows and movements. Contemp. Political Theory 2016, 15, 160-181. [CrossRef]

87. Gough, A. Working with/in/against more-than-human environmental sustainability education. Educ. J. Res. Debate 2018, 1. [CrossRef]

88. Cielemęcka, O.; Daigle, C. Posthuman sustainability: An ethos for our anthropocenic future. TheoryCult. Soc. 2019, 36, 67-87. [CrossRef]

89. Stromquist, N.P.; Monkman, K. Globalization and Education: Integration and Contestation across Cultures; Rowman \& Littlefield Publishers Inc.: Lanham, MD, USA, 2014.

90. Eilks, I.; Hofstein, A. Combining the question of the relevance of science education with the idea of education for sustainable development. In Science Education Research and Education for Sustainable Development; Eilks, I., Markic, S., Ralle, B., Eds.; Shaker: Aachen, Germany, 2014; pp. 3-14.

91. Kohl, K.; Hopkins, C.A. ESD for All: Learnings from the Indigenous ESD Global Research. J. Teach. Educ. Sustain. 2019, 21, 105-120. [CrossRef]

92. Yli-Panula, E.; Jeronen, E.; Lemmetty, P. Teaching and learning methods in geography promoting sustainability. Educ. Sci. 2020, 10, 5. [CrossRef]

93. VENRO. "Globales Lernen" als Aufgabe und Handlungsfeld Entwicklungspolitischer NichtRegierungsorganisationen; Grundsatze, Probleme und Perspektiven der Bildungsarbeit des VENRO und seiner Mitgliedsorganisationen; VENRO: Bonn, Germany, 2000.

94. Scheunflug, A. How to get Knowledge into Competences?-Challenges for Global Learning in Schools. In Proceedings of the Keynote 1: Professor Dr Annette Scheunpflug, Bamberg University, at the Conference by Globala Skolan, Linnaeus University, Växjö, Sweden, 19 November 2014.

95. Yueh, M.-C.M.; Barker, M. Framework Thinking, Subject Thinking and 'Taiwanness' in Environmental Education. Aust. J. Environ. Educ. 2011, 27, 134-148. [CrossRef]

96. Bourn, D. Global Learning and Subject Knowledge. Development Education Research Centre Research Paper No. 4; University College London, Institute of Education: London, UK, 2012; Available online: https://discovery.ucl.ac.uk/id/eprint/1476665/1/ GlobalLearningAndSubjectKnowledge.pdf (accessed on 10 September 2020).

97. Bowden, J.A. Capabilities-driven curriculum design. In Effective Learning and Teaching in Engineering; Baillie, C., Moore, I., Eds.; RoutledgeFalmer: New York, NY, USA, 2004; pp. 36-48.

98. Holdsworth, S.; Thomas, I. Competencies or capabilities in the Australian higher education landscape and its implications for the development and delivery of sustainability education. High. Educ. Res. Dev. 2020. [CrossRef]

99. Scheunpflug, A. Global education and cross-cultural learning: A challenge for a research-based approach to international teacher education. Int. J. Dev. Educ. Glob. Learn. 2011, 3, 29-44. [CrossRef]

100. Mogensen, F.; Schnack, F. The Action Competence Approach and the 'New' Discourse of Education for Sustainable Development, Competence and Quality Criteria. Environ. Educ. Res. 2010, 16, 59-74. [CrossRef]

101. Verger, A.; Bonal, X.; Zancajo, A. Indicators for a Broad and Bold Post-2015 Agenda: A Comprehensive Approach to Educational Development. Globalization, Education and Social Policies (GEPS); Open Society Foundations, Autonomous University of Barcelona: Barcelona, Spain, 2015.

102. Boeve-de Pauw, J.; Gericke, N.; Olsson, D.; Berglund, T. The effectiveness of education for sustainable development. Sustainability 2015, 7, 15693-15717. [CrossRef]

103. Fazey, I.; Schäpke, N.; Caniglia, G.; Patterson, J.; Hultman, J.; Van Mierlo, B.; Säwe, F.; Wiek, A.; Wittmayer, J.; Al Waer, H.; et al. Ten essentials for action-oriented and second order energy transitions, transformations and climate change research. Energy Res. Soc. Sci. 2018, 40, 54-70. [CrossRef]

104. Huckle, J. An Analysis of New Labour's Policy on Education for Sustainable Development with Particular Reference to Socially Critical Approaches. Environ. Educ. Res. 2008, 14, 65-75. [CrossRef]

105. Rost, J. Competencies for education for sustainability. Dev. Educ. J. 2004, 11, 6-8.

106. Agenda 2030, Transforming our World: The 2030 Agenda for Sustainable Development I Department of Economic and Social Affairs. Available online: https:/ /sdgs.un.org/2030agenda (accessed on 26 November 2020).

107. SDG Indicators. SDG Indicators-SDG Indicators (un.org). Available online: https://unstats.un.org/sdgs/indicators/database/ (accessed on 26 November 2020).

108. Hunt, F. Global Learning in Primary Schools in England: Practices and Impacts; Development Education Research Centre. Research Paper No. 9; Institute of Education, University of London: London, UK, 2012. 
109. Gwin, R.; Foggin, J.M. Badging for Sustainable Development: Applying EdTech Micro-Credentials for Advancing SDGs amongst Mountain and Pastoralist Societies. Preprints 2020, 2020030402. Available online: https://www.preprints.org/manuscript/2020 03.0402/v1 (accessed on 10 September 2020).

110. Thakur, R. The United Nations and the North-South Partnership: Connecting the Past to the Future. Ethics Int. Aff. 2020, 34, 305-317. [CrossRef]

111. Godsmark, C.N. Inspiring climate action without inducing climate despair. Lancet Planet. Health 2020, 4, e169-e170. [CrossRef]

112. Chan, T.; Leung, A. Illuminate: A Simulation Game to Instill Grounded Hope in Youth for Climate Action. In Extended Abstracts of the 2020 Annual Symposium on Computer-Human Interaction in Play; Association for Computing Machinery: New York, NY, USA, 2020; pp. 47-49. [CrossRef]

113. Steffen, W.; Richardson, K.; Rockström, J.; Cornell, S.E.; Fetzer, I.; Bennett, E.M.; Folke, C. Planetary boundaries: Guiding human development on a changing planet. Science 2015, 347, 1259855. [CrossRef]

114. Rockström, J. Big World, Small Planet: Abundance within Planetary Boundaries; Max Ström: Stockholm, Sweden, 2015.

115. Lade, S.J.; Steffen, W.; De Vries, W.; Carpenter, S.R.; Donges, J.F.; Gerten, D.; Hoff, H.; Newbold, T.; Richardson, K.; Rockström, J. Human impacts on planetary boundaries amplified by Earth system interactions. Nat. Sustain. 2020, 3, 119-128. [CrossRef]

116. UNEP. Global Biodiversity Outlook 5; Secretariat of the Convention on Biological Diversity: Montreal, QC, Canada, 2020; ISBN 9789292256883. Available online: www.cbd.int/GBO5 (accessed on 10 September 2020).

117. Mir, W. Financing the United Nations Secretariat: Resolving the UN's Liquidity Crisis; International Peace Institute: New York, NY, USA, 2020.

118. Wiek, A.; Bernstein, M.J.; Laubichler, M.; Caniglia, G.; Minteer, B.; Lang, D.J. A global classroom for international sustainability education. Creat. Educ. 2013, 4, 19-28. [CrossRef]

119. Scheunpflug, A. Global Learning: Educational research in an emerging field. Key Note at ECER 2019. Eur. Educ. Res. J. 2020, $13,1-11$. [CrossRef]

120. Lee, Y.S.; Schottenfeld, M.A. Internationalising experiential learning for sustainable development education. J. Educ. Sustain. Dev. 2012, 6, 341-354. [CrossRef]

121. Heinrich, W.F.; Habron, G.B.; Johnson, H.L.; Goralnik, L. Critical thinking assessment across four sustainability-related experiential learning settings. J. Exp. Educ. 2015, 38, 373-393. [CrossRef]

122. World Economic Situation Prospects. Statistical Annex; United Nations: New York, NY, USA, 2020.

123. UN General Assembly. United Nations Millennium Declaration: Resolution 55/2. 2000. Available online: https://www.un.org/en/ development/desa/population/migration/generalassembly/docs/globalcompact/A_RES_55_2.pdf (accessed on 26 November 2020).

124. Kuntsman, A.; Rattle, I. Towards a paradigmatic shift in sustainability studies: A systematic review of peer reviewed literature and future agenda setting to consider environmental (Un) sustainability of digital communication. Environ. Commun. 2019, 13, 567-581. [CrossRef]

125. Gough, A.G. Globalizing environmental education: What's language got to do with it? J. Exp. Educ. 1993, 16, 32-39. [CrossRef]

126. Köhler, J.; Geels, F.W.; Kern, F.; Markard, J.; Onsongo, E.; Wieczorek, A.; Alkemade, F.; Avelino, F.; Bergek, A.; Fünfschilling, L.; et al. An agenda for sustainability transitions research: State of the art and future directions. Environ. Innov. Soc. Transit. 2019, 31, 1-32. [CrossRef]

127. Hamel, R.E. The dominance of English in the international scientific periodical literature and the future of language use in science. Aila Rev. 2007, 20, 53-71. [CrossRef]

128. Gui, Q.; Liu, C.; Du, D. Globalization of science and international scientific collaboration: A network perspective. Geoforum 2019, 105, 1-12. [CrossRef]

129. ANGEL. Global Education Digest 2020; Development Education Research Centre, UCL Institute of Education: London, UK, 2019. Available online: https://discovery.ucl.ac.uk/id/eprint/10112144/1/Digest\%202020\%20Online.pdf (accessed on 26 November 2020). 